\title{
CTCF Governs the Identity and Migration of MGE-Derived Cortical Interneurons
}

\author{
Adrienne Elbert, ${ }^{1,2}$ Daniel Vogt, ${ }^{3}$ Ashley Watson, ${ }^{1,2}$ Michael Levy, ${ }^{1,2}$ Yan Jiang, ${ }^{1,2}$ Emilie Brûlé, ${ }^{1,2}$ Megan E. Rowland, ${ }^{1,2}$ \\ 이ohn Rubenstein, ${ }^{3}$ and $\mathbb{C N}^{-N a t h a l i e ~ G . ~ B e ́ r u b e ́ ~}{ }^{1,2}$ \\ ${ }^{1}$ Children's Health Research Institute, London, Ontario, Canada, ${ }^{2}$ Department of Paediatrics, Schulich School of Medicine and Dentistry, the University of \\ Western Ontario, Victoria Research Laboratories, London, Ontario, Canada N6C 2V5, and '3Department of Psychiatry, Neuroscience Program and the Nina \\ Ireland Laboratory of Developmental Neurobiology, University of California San Francisco, San Francisco 94143-2611
}

The CCCTC-binding factor (CTCF) is a central regulator of chromatin topology recently linked to neurodevelopmental disorders such as intellectual disability, autism, and schizophrenia. The aim of this study was to identify novel roles of CTCF in the developing mouse brain. We provide evidence that CTCF is required for the expression of the LIM homeodomain factor LHX6 involved in fate determination of cortical interneurons (CINs) that originate in the medial ganglionic eminence (MGE). Conditional Ctcf ablation in the MGE of mice of either sex leads to delayed tangential migration, abnormal distribution of CIN in the neocortex, a marked reduction of CINs expressing parvalbumin and somatostatin (Sst), and an increased number of MGE-derived cells expressing $L h x 8$ and other markers of basal forebrain projection neurons. Likewise, Ctcf-null MGE cells transplanted into the cortex of wild-type hosts generate fewer Sst-expressing CINs and exhibit lamination defects that are efficiently rescued upon reexpression of LHX6. Collectively, these data indicate that CTCF regulates the dichotomy between $L h x 6$ and $L h x 8$ to achieve correct specification and migration of MGE-derived CINs.

Key words: cell transplantation; chromatin structure; CTCF; GABAergic interneurons; intellectual disability; schizophrenia

Significance Statement

This work provides evidence that CCCTC-binding factor (CTCF) controls an early fate decision point in the generation of cortical interneurons mediated at least in part by Lhx6. Importantly, the abnormalities described could reflect early molecular and cellular events that contribute to human neurological disorders previously linked to CTCF, including schizophrenia, autism, and intellectual disability.

\section{Introduction}

The cerebral cortex consists of pyramidal excitatory neurons and inhibitory interneurons. The latter produce GABA to provide the rhythmic inhibitory activity that synchronizes pyramidal cell firing in mature neuronal circuits of the cortex (for review, see Tremblay et al., 2016). Not surprisingly, perturbation of the cortical GABAergic system underlies several neurodevelopmental

\footnotetext{
Received Dec. 11, 2017; revised 0ct. 12, 2018; accepted 0ct. 12, 2018

Author contributions: N.G.B., A.E., D.V., and J.R. designed research; A.E., D.V., A.W., Y.J., E.B., and M.E.R. performed research; N.G.B., A.E., D.V., A.W., and M.L. analyzed data; N.G.B. and A.E. wrote the paper.

This work was supported by the Canadian Institutes for Health Research (Grant MOP142268 to N.G.B.) and the National Institutes of Mental Health-National Institutes of Health (Grant R01 MH081880 to J.R.). A.E. was supported by scholarship funding from CIHR Vanier and Ontario Mental Health Foundation. A.W. was supported by a Natural Science and Engineering Research Council (NSERC) Canadian Graduate Scholarship. We thank Dr. Neils Galjart for the Ctcffloxed mice and Dr. Aleksandar Rajkovic for the Lhx8 antibody.

J.R. is cofounder, stockholder, and currently on the scientific board of Neurona, a company studying the potential therapeutic use of interneuron transplantation. The remaining authors declare no competing financial interests.

Correspondence should be addressed to Dr. Nathalie G. Berubè, University of Western Ontario, 800 Commissioners Road East, London, Ontario N6C 2V5, Canada. E-mail: nberube@uwo.ca.

https://doi.org/10.1523/JNEUROSCI.3496-17.2018

Copyright $\odot 2019$ the authors $\quad 0270-6474 / 19 / 390177-16 \$ 15.00 / 0$
}

disorders, including Down syndrome (Pérez-Cremades et al., 2010; Ruiz-Mejias et al., 2016), fragile X syndrome (Gibson et al., 2008; Paluszkiewicz et al., 2011), and nonsyndromic autism spectrum disorder (ASD) (Blatt and Fatemi, 2011; Hashemi et al., 2017), and pharmacological modulation of GABA receptors has been therapeutic in some contexts (Potier et al., 2014; Lozano et al., 2015). Recently, the transplantation of immature interneurons into the postnatal cortex has been explored as an alternative to pharmacological therapy in mouse models of epilepsy (Southwell et al., 2014; Hammad et al., 2015; Chohan and Moore, 2016). The laminar position and marker expression of cortical interneurons (CINs) depend more on intrinsic than extrinsic factors and transplanted cortical GABAergic interneurons have the potential to integrate into existing circuits. Understanding the developmental steps and regulatory events governing CIN development is thus essential to generating interneurons for successful therapeutic transplantations.

In mice, the majority of CINs are mainly produced in the ventral telencephalon in transient progenitor structures called the medial ganglionic eminence (MGE) and the caudal gangli- 
onic eminence (CGE). MGE- and CGE-derived interneurons migrate tangentially into the developing cortical marginal and intermediate zones before radially invading the cortical plate and forming connections with the cortical pyramidal neurons (Marín, 2013). Transcriptional cascades in the MGE result in a peak of neurogenesis between embryonic days 12 (E12) to E14 that generates the somatostatin (Sst)- and parvalbumin (Pv)-expressing CIN subtypes (Xu et al., 2004; Miyoshi and Fishell, 2011). A subset of newly generated neurons and secondary progenitors located in the subventricular zone of the MGE express both $L h x 6$ and $L h x 8$, two LIM homeobox factors with partially overlapping function (Marin et al., 2000; Fragkouli et al., 2009). The cells destined to become CINs express only Lhx6, whereas the neurons that express $\operatorname{Lh} x 8$ (some in combination with $\operatorname{Lh} x 6$ ) are fated to become cholinergic or GABAergic neurons of the basal forebrain (Fragkouli et al., 2005, 2009). Lhx6-null interneurons resemble CGE-derived neurogliaform interneurons with regard to marker expression, laminar position, and electrophysiology (Vogt et al., 2014), indicating that LHX6 specifies the fate of MGE-derived CINs.

CCCTC-binding factor (CTCF) is a ubiquitously expressed protein that orchestrates loop formation in chromatin by binding to a consensus sequence and simultaneously dimerizing or partnering with other chromatin-associated proteins such as the cohesin complex (for review, see Merkenschlager and Nora, 2016). These loops can bring distant genomic elements such as promoters and enhancers into close proximity or may act as a barrier, such as when CTCF functions as an insulator protein. In parallel, emerging evidence suggests that CTCF is required for normal development and functioning of the CNS. De novo mutations in one copy of the human CTCF gene were recently identified in five patients with microcephaly, intellectual disability (ID), and short stature (Gregor et al., 2013; Bastaki et al., 2017). Two individuals with ID screened as part of a cohort selected for ASD were also identified as having mutations in one allele of CTCF (Iossifov et al., 2014). Polymorphisms in and around the CTCF gene have also been associated with schizophrenia in two different patientcontrol cohorts (Juraeva et al., 2014). Moreover, CTCF has been shown to regulate the expression of the protocadherin membrane adhesion proteins for which the combinatorial expression in neurons is thought to underlie the specificity of neuronal connectivity (Hirayama et al., 2012). The analysis of dorsal projection neurons in Ctcf-deficient mice revealed defects in dendritic arborization and reduced spine density (Hirayama et al., 2012). Viral-mediated knock-down of Ctcf in hippocampal cells also results in reduced spine density and leads to impaired learning (Sams et al., 2016).

In this study, we present our findings from Ctcf gene inactivation in the developing mouse ventral telencephalon. We show that CTCF expression is required for the normal development and fate specification of MGE-derived CINs. Ctcf deletion results in reduced expression of $\operatorname{Lh} x 6$ and an upregulation of $\operatorname{Lhx} 8$, resulting in aberrant fate specification and reduced number of $\mathrm{PV}^{+}$ and $\mathrm{SST}^{+}$CIN subtypes. Reintroduction of Lhx6 in CTCF-null MGE progenitors is sufficient to reestablish the normal number of SST ${ }^{+}$interneurons and lamination pattern in transplantation experiments. These findings suggest that loss of CTCF during telencephalon development can affect postnatal CIN number and therefore inhibitory functions, perhaps contributing to cognitive abnormalities.

\section{Materials and Methods}

Mice and genotyping. Animal studies were approved by the University of Western Ontario Animal Care Committee according to guidelines established by the Canadian Council on Animal Care. Mice were housed in the London Regional Cancer Program vivarium (12 h light/dark cycle) and were provided with regular chow and water ad libitum. $C t c f^{\mathrm{fl} / \mathrm{fl}}$ mice were generated by Heath et al. (2008) on a C57BL/6 background. The NestinCre mice (C57BL/6 background) were described previously (Bérubé et al., 2005). Bbc3/Puma ${ }^{-1-}$ (stock \#011067), Nkx2.1Cre (stock \#008661), and Rosa ${ }^{\mathrm{mTmG}}$ (stock \#007576) mice were purchased from the The Jackson Laboratory. Mice carrying Rosa ${ }^{\mathrm{mTmG}}$ are of a mixed background and were bred to $C t c f^{\mathrm{fl} / \mathrm{fl}}$ mice to homozygosity.

$C t c f^{\mathrm{fl} / \mathrm{fl}}$ and NestinCre $\mathrm{C}^{+/-}$mice were mated and the resultant $\mathrm{Ctcf} \mathrm{fl}^{\mathrm{fl} / \mathrm{wt}}$ : NestinCre ${ }^{\prime-}$ offspring were time mated to Ctcf ${ }^{\mathrm{fl} / \mathrm{fl}}$ mice to generate Ctcf conditional knock-out embryos $\left(\right.$ Ctcf $^{\mathrm{fl} / \mathrm{fl}} ; \mathrm{NestinCre}^{+/-}$, hereafter referred to as $C t c f^{\text {Nes-Cre }}$ ), as described previously (Watson et al., 2014). $C t c f^{\text {Nes-Cre }}$ embryos of either sex exhibit efficient Cre-mediated recombination at loxP sites flanking exons 3-12 of the Ctcflocus in neuroprogenitors beginning at approximately E11(Watson et al., 2014). Embryos of either sex without the NestinCre transgene and wild-type Ctcf expression were used as controls.

$C t c f^{\mathrm{Nkx}-\mathrm{Cre}}$ embryos and mice were generated in the same fashion as described above for the $C t c f^{\mathrm{Nes}-\mathrm{Cre}}$ mice. Nkx2.1Cre mice were maintained on a C57BL/ 6 background, with the exception of the transplantation experiments, which were performed using Nkx2.1Cre mice maintained on a CD1 background. For the mice used for transplantation experiments, care and procedures were performed according to the University of California at San Francisco Laboratory Animal Research Center guidelines.

For timed mating, time of conception was considered to be the midnight before vaginal plug discovery. To label proliferative cells, pregnant dams were injected intraperitoneally with BrdU labeling agent (GE Healthcare Life Sciences) at $1 \mathrm{ml} / 100 \mathrm{~g}$ body weight, as described previously, $1 \mathrm{~h}$ before being killed (Watson et al., 2014).

P20-P22 mouse brains were harvested by transcardial perfusion with $20 \mathrm{ml}$ of PBS (DEPC-treated) followed by perfusion with $20 \mathrm{ml}$ of $4 \%$ paraformaldehyde (PFA)/PBS (DEPC-treated) before brain dissection.

RNA-sequencing (RNA-Seq) analysis. Telencephalons of two E14

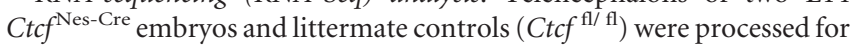
RNA-Seq at Otogenetics. Raw reads were aligned to mouse genome mm10 using STAR (Dobin et al., 2013) version 2.5.3a with GENCODE M11 primary annotations. Count matrices were generated using the $\mathrm{R}$ GenomicAlignments package (Lawrence et al., 2013) and normalized using DeSeq2 (Love et al., 2014). Low-expressing genes (counts $<2 \%$ of the average of all samples) were removed and genes with an average change of 1.5 -fold or greater were used for downstream analysis by The Protein ANalysis THrough Evolutionary Relationships (PANTHER; http://pantherdb.org/).

$q R T-P C R$ analysis. For qRT-PCR, total RNA was extracted using an RNeasy Mini kit (Qiagen) and cDNA was synthesized using SuperScript II Reverse Transcriptase (Invitrogen), as described previously (Watson et al., 2014). Primer sequences used for qRT-PCR are listed in Table 1. All primers in this study were designed using Primer3 software (http:// bioinfo.ut.ee/primer3-0.4.0/primer3/). PCR amplification was performed using the iQ SYBR Green supermix (Bio-Rad) under the following conditions: $95^{\circ} \mathrm{C}$ for $3 \mathrm{~min}\left(195^{\circ} \mathrm{C}\right.$ for $10 \mathrm{~s}, 58^{\circ} \mathrm{C}$ for $20 \mathrm{~s}, 72^{\circ} \mathrm{C}$ for $30 \mathrm{~s} \times 35$ ) and $72^{\circ} \mathrm{C}$ for $5 \mathrm{~min}$. A melting curve for each sample was generated from $55^{\circ} \mathrm{C}$ to $95^{\circ} \mathrm{C}$ in increments of $1^{\circ} \mathrm{C}$ and PCR products were resolved on agarose gels to verify band size. $\beta$-actin transcript was quantified and used for normalization of the data.

Immunofluorescence (IF) and in situ hybridization (ISH) staining. Dissected samples were incubated in 4\% PFA/PBS (DEPC-treated) overnight and then dehydrated in $30 \%$ sucrose until samples sank to the bottom before being frozen in Cryomatrix (optimal cutting temperature medium) and sectioned at $8 \mu \mathrm{m}$ thickness. IF and BrdU labeling was performed as described previously (Watson et al., 2014). For IF, slides with sections were rehydrated in PBS and then incubated overnight $(8-16 \mathrm{~h})$ with the primary antibody at $4^{\circ} \mathrm{C}$ in $0.3 \%$ Triton $\mathrm{X}-100$ in PBS 
Table 1. Primer sequences used for genotyping, qRT-PCR, and ISH probe synthesis

\begin{tabular}{|c|c|c|}
\hline Gene (purpose) & Forward sequence & Reverse sequence \\
\hline Ctcf (genotype) & CTAGGAGTGTAGTTCAGTGAGGCC & GCTCTAAAGAAGGTTGTGAGTTC \\
\hline Sry (genotype) & GCAGGTGGAAAAGCCTTACA & AAGCTTTGCTGGTTTTTGGA \\
\hline Cre (genotype) & TGACCAGAGTCATCCTTAGCG & AATGCTTCTGTCCGTTTGCC \\
\hline Rosa mTmG (genotype) & СTCTGCTGCCTCCTGGCTTCT & $\begin{array}{l}\text { WT: GGAGGCGGATCACAAGCAATA } \\
\text { MUT: TCAATGGGGGGGGTCGTT }\end{array}$ \\
\hline B actin (qRT-PCR) & CTGTCGAGTCGCGTCCACCC & ACATGCCGGAGCCGTTGTCG \\
\hline Lhx8 (qRT-PCR) & CCACCCATGTTGGAAGAAAT & CATTGGATGGGGTAACAAGG \\
\hline Cxcr4 (qRT-PCR) & GAAGTAGATGGTGGGCAGGA & ACGGCTGTAGAGCGAGTGTT \\
\hline Sst (qRT-PCR) & GGGCATCATTCTCTGTCTGG & GAGGCAAGGAAGATGCTGTC \\
\hline Lhx8 (probe) & GAAGAGCGATCAGATGTTTGTG & TAATACGACTCACTATAGGGCACCTGTATGACACGTCTGCTT \\
\hline Pvalb (probe) & GGATGTCGATGACAGACGTG & TAATACGACTCACTATAGGGACTCAACCCCTTCCCTTCC \\
\hline VIP (probe) & СCTGGCATTCCTGATACTCTTC & TAATACGACTCACTATAGGGATTCTCTGATTTCAGCTCTGCC \\
\hline
\end{tabular}

at the following dilutions: rabbit anti-CTCF (1:400; Cell Signaling Technology), mouse anti-BrdU (1:50; BD Biosciences), rabbit anti-Nkx2.1 (1:100; Santa Cruz Biotechnology), and goat anti-SP8 (1:100; Santa Cruz Biotechnology). For BrdU, tissue sections were treated with $2 \mathrm{~N} \mathrm{HCl}$ and then $0.1 \mathrm{M} \mathrm{Na}_{2} \mathrm{~B}_{4} \mathrm{O}_{7}, \mathrm{pH} 8.5$, before primary antibody incubation. For anti-SP8 staining, slides were heated in $10 \mathrm{~mm}$ sodium citrate and then blocked with $10 \%$ NGS/0.3\% Triton X-100 in PBS for $1 \mathrm{~h}$ before incubation with the primary antibody. The following morning, sections were washed with $0.3 \%$ Triton X-100 in PBS and incubated with the corresponding secondary antibody (1:800 Alexa Fluor 594 or 488; Invitrogen) for $1 \mathrm{~h}$. Sections were then washed again and stained with DAPI (Sigma-Aldrich)

ISH riboprobes were synthesized as follows, with the exception of the Reelin ISH probe, which was a kind gift from the Rubenstein laboratory; Template DNA was PCR amplified using primers; the reverse primer was labeled with the T7 recognition sequence at the $5^{\prime}$ end (Table 2). Digoxigenin-labeled riboprobes were then synthesized from the gelpurified template DNA using T7 (antisense probe) polymerase (Roche) according to the manufacturer's instructions. For ISH, sections were incubated overnight (12-18 h) with antisense digoxigenin-labeled riboprobes at $65^{\circ} \mathrm{C}$ in a humidified chamber. Riboprobes were diluted in formamide-based hybridization buffer at 1:1000 from stock. The following morning, sections were washed in formamide-based ISH wash buffer and then maleic acid buffer containing Tween 20 (MABT) before incubation with alkaline phosphatase conjugated anti-figoxigenin Fab fragments (Roche) overnight. Excess antibody was removed with a series of MABT and prestaining buffer washes before riboprobe detection using the NBT/BCIP system (Roche) in a polyvinyl alcohol-based solution. After staining, the reaction was ended with vigorous PBS washing. Sections were cleared by dehydration in serial ethanol dilutions (70\%, 90\%, and $100 \%$ ) and xylene and then mounted.

Microscopy and imaging. Fluorescence and light microscopy was performed using an inverted (DMI 6000b) Leica microscope. Light microscopy was also performed with the Aperio CS2 digital pathology scanner (Scanscope; Leica). For transplantation experiments, fluorescent images were taken using a Coolsnap camera (Photometrics) mounted on a Nikon Eclipse 80i microscope using NIS Elements acquisition software (Nikon). Images were processed with Volocity (PerkinElmer), Imagescope (Leica), ImageJ, and Adobe Photoshop.

Coimmunoprecipitation and Western blot analysis. Total protein was extracted from embryonic telencephalon or MGE using standard protocol with RIPA buffer and quantified with the Bradford assay. For immunoprecipitation, E13.5 MGEs were pooled from wild-type embryos and the protein was incubated overnight with anti-CTCF, anti-NKX2.1, or
IgG antibody (mock IP). Antibody-protein complexes were incubated with protein-G Dynabeads and isolated by centrifugation. After washing, interactions were disrupted and proteins were detected by Western blotting as described below.

Protein lysates were resolved on an 8\% SDS-polyacrylamide gel and transferred to a nitrocellulose membrane. Anti-CTCF (1:1000; Cell Signaling Technology), anti-NKX2.1 (1:2000; Santa Cruz Biotechnology), and anti- $\beta$-Actin (1:7000; Sigma-Aldrich) were used to probe the membrane, followed by secondary detection with the corresponding horseradish peroxidase-conjugated antibodies (1:4000; GE Healthcare Life Sciences). Protein was quantified using ImageJ software (version 1.47).

ChIP sequencing. ChIP in MGE was performed as described previously for mouse forebrain (Watson et al., 2014). E13.5 MGE was dissected and pipetted up and down in DMEM to create a single-cell suspension. Cells were fixed in $1 \%$ formaldehyde and then lysed in SDS buffer. Chromatin was sonicated to an average size of $500 \mathrm{bp}$ and then $1 / 25$ of total chromatin was set aside (input). The rest of the chromatin was incubated overnight with rabbit anti-CTCF antibody (Cell Signaling Technology) or rabbit IgG as a control. CTCF-bound chromatin fragments were then purified using magnetic Dynabeads (Invitrogen) and crosslinking was reversed. ChIP-sequencing (ChIP-Seq) reads were aligned to mouse genome mm9 or mm10 using Bowtie2 (Langmead and Salzberg, 2012) version 2.3.2 using default settings. Peaks were called using MACS2 (Zhang et al., 2008) version 2.1.1.20160309 with $p=0.001$. Wig files were generated using deepTools (Ramírez et al., 2014) and overlapping peaks were identified using Bedtools (Quinlan and Hall, 2010).

T4 ELISA. Blood was collected from P20 mice by transcardiac puncture using an EDTA-coated syringe, $\mathrm{pH}$ 7.0. Blood was centrifuged for 10 $\min (14,000 \mathrm{RPM})$ at $4^{\circ} \mathrm{C}$ and then the plasma collected and stored at $-20^{\circ} \mathrm{C}$. Plasma was loaded onto the T4 ELISA kit (T4044T-100; Calbiotech) according to manufacturer's protocols.

Cell counts. To determine the density of marker-positive cells in P20P22 cortex, results from a representative rectangle in somatosensory cortex from 3-6 serial cryosections ( $8 \mu \mathrm{m}$ thickness) per animal were averaged. Because the number of transplanted cells is low, tissue section thickness of $25 \mu \mathrm{m}$ was used to ensure adequate power to detect differences between test and control samples for transplantation experiments.

The cortical rectangle was $\sim 400 \mu \mathrm{m}$ wide and depth was determined by inclusion of all cortical layers. Areas within the indicated brain regions were calculated (in square millimeters) from microscope images in Volocity or Imagescope software and counts were performed in a manner blinded to genotype. For Gad1 and Reelin marker-positive cell counts, the cortex was divided into 10 equal-sized horizontal bins to simultane- 
ously determine laminar changes. The first cortical bin location and size corresponds approximately to the marginal zone.

For cell counts in the MGE, images were acquired at a magnification of $20 \times$ to allow for sufficient area and visual quality. To determine cell densities for $\mathrm{BrdU}^{+}, \mathrm{ki} 7^{+}$, and $\mathrm{PH} 3^{+}$cells at E14, standard parameters were set for a free-hand-generated shape. The shape edges followed the contour of the MGE at $\sim 100 \mu \mathrm{m}$ wide and the depth of the MGE ventricular zone at $\sim 100 \mu \mathrm{m}$ deep.

Cloning. The DlxI12b-GFP-T2a-Lhx6 vector (Vogt et al., 2014) was modified to remove loxP sites that flanked the expression cassettes. PCR was used to generate a $D l x I 12 b-G F P$ fragment that harbored a 5' XbaI restriction enzyme site, but excluded the loxP site from the original vector and a $3^{\prime}$ primer against GFP that included a BsrGI site. This product was then ligated into the same backbone in the $5^{\prime} \mathrm{XbaI}$ and $3^{\prime} \mathrm{BsrGI}$ sites. The resulting vector lacked a flanking loxP site and could be expressed in cells expressing Cre recombinase. Vectors were verified by restriction digest and sequencing.

Lentivirus generation. HEK293T cells grown in DMEM H21 with 10\% FBS were transfected using Lipofectamine 2000 (Thermo Fisher Scientific) with the lentiviral expression vector and three helper plasmids ( $p V S V-g, p R S V r$, and $p M D L g-p R R E$ ) to generate lentivirus particles as described previously (Vogt et al., 2015). Media containing lentiviruses was collected after $4 \mathrm{~d}$ and filtered through a 0.45 low-protein-binding membrane to remove cells and large debris. The filtered medium was pooled and ultracentrifuged at $100,000 \times g$ for $2.5 \mathrm{~h}$ at $4^{\circ} \mathrm{C}$. The supernatant was removed and the pellet was resuspended overnight at $4^{\circ} \mathrm{C}$ in sterile PBS and then stored at $-80^{\circ} \mathrm{C}$ until use.

MGE transplantation. MGE transplantation and rescue assays have been described previously (Vogt et al., 2014). Briefly, E13.5 MGE tissue from either Ctcf flox/wt:NestinCre ${ }^{+}$(controls) or Ctcf flox/flox :NestinCre $^{+}$ (knock-out) embryos were harvested and dissociated into a single-cell suspension before injection into a wild-type P1 host. For rescue experiments, MGE cells from Ctcf flox/flox:NestinCre ${ }^{+}$embryos were collected in the same manner and then incubated with lentiviruses that expressed Lhx6 and Gfp for $30 \mathrm{~min}$ at $37^{\circ} \mathrm{C}$ in media at physiological $\mathrm{pH}$ before transplantation. Transplanted cells were allowed to develop in vivo for $35 \mathrm{~d}$ before analysis. Immunofluorescence staining of sections at day 35 were performed with the following antibodies: rabbit anti-GFP (Clontech, 1:2000), chicken anti-GFP (Aves Laboratories, 1:2000), rabbit anti-PV (Swant, 1:500), mouse anti-PV (Millipore, 1:500), rat anti-SST (Millipore, 1:200), or guinea pig anti-LHX8 (a generous gift from Aleksandar Rajkovic, University of Pittsburgh).

Experimental design and statistical analysis. Sample sizes of test animals were chosen based on the minimum number of animals required, in our experience, to detect differences between control and experimental samples. To minimize within-pair variation, we used littermate-matched, sex-matched animals. Because we have detected no difference in phenotype between male and female animals in past or present study of this animal model, results from both sexes were combined.

Given our previous work in the NesCre Ctcf model, transcriptional changes in the absence of CTCF were investigated at the E13.5-E14.5 developmental age, a time before onset of cell death. Given the early, highly penetrant lethality of NesCre-mediated deletion of Ctcf, we selected a new Cre driver line for specific deletion of $C t c f$ from the MGE. Nkx2.1Cre mice were selected because this model is well characterized, with early Cre expression and limited off-target effects, which include Cre-mediated deletion in lung and thyroid tissues. The E15.5-E16.5 time point was selected to analyze migration of MGE-derived interneurons based on previous studies showing that a large proportion of MGEderived interneurons have completed tangential migration by this time. After birth, animals were weighed daily and survival was tracked. The P20-P22 time point was selected based on animal survival and for comparison with the study by Vogt et al. (2014) and the histological data presented from this time point were generated from six conditional knock-outs and their control littermates (two female pairs and four male pairs).

Tissue sections were taken in series (10 sections apart), as opposed to sequentially. For cell density counts, one slide with five series sections was stained per marker per animal. Given some sections were not of appro- priate quality, this allowed for three to five sections to be photographed and used for quantification. A representative image was selected among these. Counting was done by an individual blinded to genotype. Markers for this study were selected based on careful review of the literature. Gapdh and $\beta$-actin were used for normalization based on their established use as controls and previous use in these models. For qRT-PCR of $L h x 6$, Lhx8, Sst, and Gbx2, three pairs of control and knock-out animals were used. For cell counts of BrdU, Ki67, and PH3, three pairs were used. For cell counts of interneuron markers, sample sizes were as follows: Gad1, $n=3$; Reelin, $n=3$; Vip, $n=3 ; C r, n=4 ; P v, n=4 ;$ Sst, $n=3$; and SP8, $n=3$. All other sample sizes are listed in the figure legends. We analyzed qRT-PCR, Western blot, ELISA, and cell counts with two-tailed Student's $t$ tests. Because Gad1 and Reelin are interneuron markers that are present across multiple laminar layers, the cortex was divided into bins for these markers to investigate lamination. The bins were equal in size for ease and consistency between samples and the number 10 was selected as then the width of "bin 1" would approximate the marginal zone layer, which was of particular interest based on the Vogt et al. (2014) study. Repeated-measures ANOVA was used for evaluation of the binned data across the cortex.

Given the association of transcriptional changes in Lhx6 with the Ctcf mutant phenotype, we designed a rescue experiment to demonstrate a causal link. The reexpression of $\operatorname{Lh} x 6$ using lentiviral construct was chosen due to the previous success of this method and the fact that it eliminates confounding effects of tissue-autonomous Ctcf deletion and we could thus investigate Ctcf-null MGE cells in a wild-type tissue environment. In addition, this method eliminated the potential confounder of impaired tangential migration because cells are transplanted directly into the cortical milieu.

\section{Results}

\section{Altered expression GABAergic neuron differentiation genes in the CTCF-null telencephalon}

We previously reported telencephalon defects upon conditional inactivation of Ctcf in the embryonic brain using the NestinCre driver line of mice (Watson et al., 2014), which deletes Ctcf in early neural progenitors (radial glia). Analysis of the dorsal forebrain of E16.5 Ctcf $f^{\text {Nes-Cre }}$ revealed extensive Tp53- and Pumadependent cell death and premature differentiation of neural precursor cells, leading to depletion of the progenitor pool (Watson et al., 2014). To determine the effects of Ctcf inactivation on gene expression, we performed RNA sequencing of $C t c f^{\mathrm{Nes} C r e}$ and littermate control telencephalon at E14 before apoptosis induction. Using the criteria of a minimum expression of $2 \%$ of the average reads and a minimum average fold change of 1.5 , we generated a list of genes $(N=2024)$ with altered expression in the $C t c f^{\text {Nes-Cre }}$ E14 telencephalon. Approximately half of these genes $(n=1050)$ exhibited decreased expression and included a large number of the clustered $\mathrm{Ca}^{2+}$-binding protocadherin $(P c d h)$ genes, with a more pronounced effect on Pcdh- $\beta$ genes (Fig. $1 A, B)$. We confirmed the effect of $C t c f$ inactivation on $P c d h$ genes by qRT-PCR (Fig. 1C). These results expand on previous reports by demonstrating that CTCF regulates Pcdh cluster genes in the embryonic brain before neuronal network establishment. However, we found that many genes displaying expression differences in the $C t c f^{\text {Nes-Cre }}$ E14 telencephalon were involved in the early development and differentiation of GABAergic interneurons (Fig. 1A). Indeed, the most significantly enriched Gene Ontology (GO) Biological Processes term with $>2.0$ fold enrichment (PANTHER version 11.1, Pantherdb.org) was GABAergic neuron differentiation (Fig. 1D), suggesting a potential novel role of CTCF in the development of inhibitory interneurons. The list of genes included $L h x 6$, an important upstream regulator of GABAergic neuron fate specification (Liodis et al., 2007), and several Lhx6-dependent genes or downstream effectors, includ- 

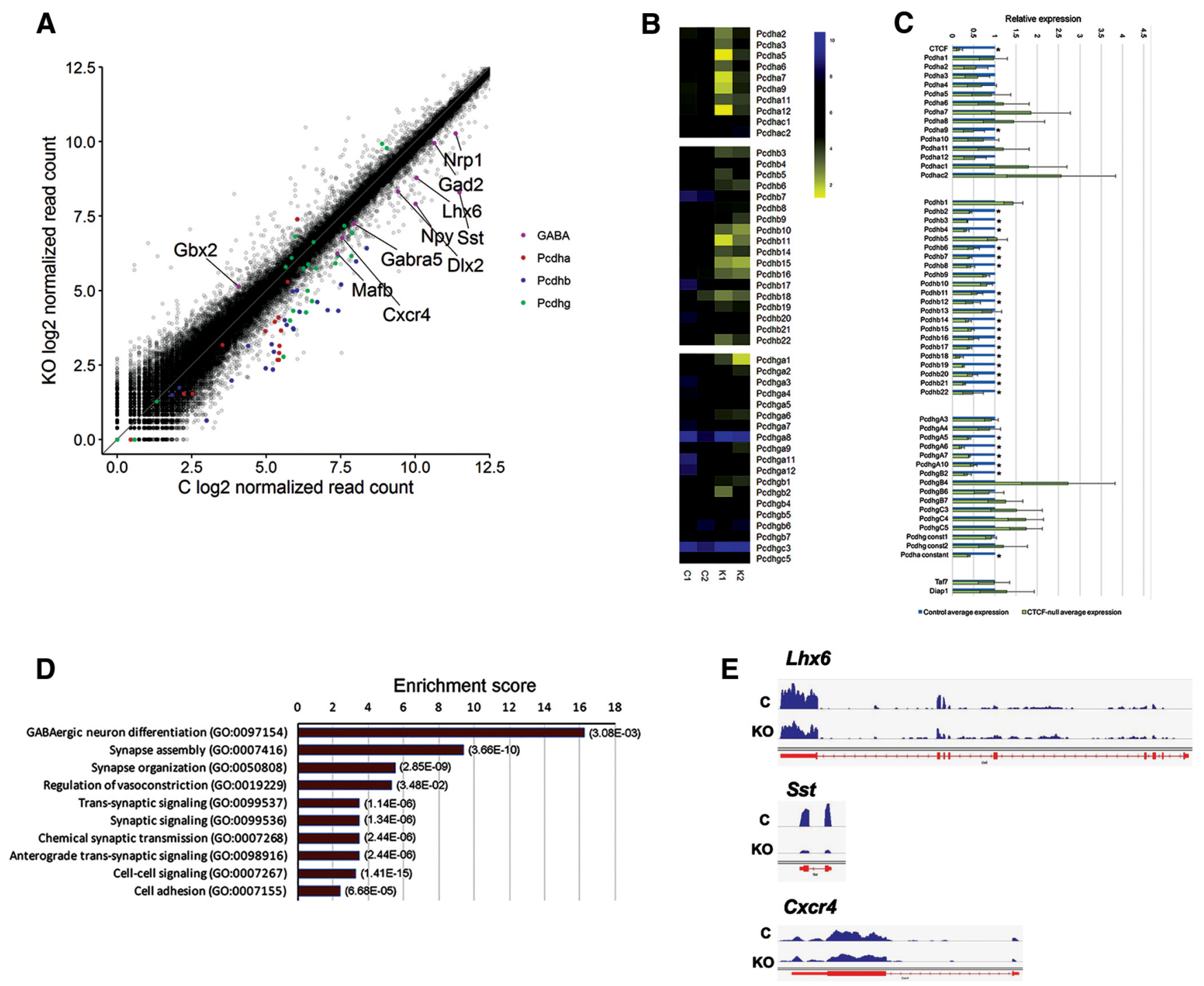

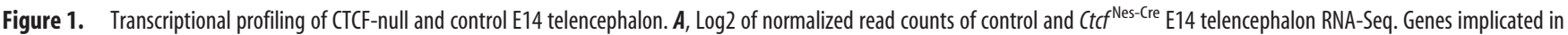
GABAergic differentiation and Pcdh cluster genes are highlighted in color. $\boldsymbol{B}$, Heat maps of $P c d h$ gene expression across the $\alpha, \beta$, and $\gamma$ clusters from RNA-Seq analysis. $C$, qRT-PCR of Pcdh genes from clusters $\alpha, \beta$, and $\gamma$ in Ctcf ${ }^{\text {Nes-Cre }}$ normalized to littermate controls and to Gapdh. $n=3$. Error bars indicate SEM. Asterisks indicate $p<0.05$ using Student's $s$ test, not corrected for multiple testing. Taf7 and Diap 1 are genes located between the Pcdh- $\beta$ and Pcdh- $\gamma$ clusters. D, Top 10 enriched G0 terms for biological processes of genes downregulated in the Ctc $f^{\text {Nes-Cre }}$ E14 telencephalon. The list was generated using the PANTHER overrepresentation test. $p$-values with a Bonferroni correction are shown on the right for each category. E, University of California Santa Cruz genome browser view of RNA-Seq data of selected genes involved in GABAergic interneuron differentiation.

ing Sst and Cxcr4 (Fig. 1E). Additional GO enrichment terms were related to synaptic transmission, which is expected from the large number of altered $P c d h$ genes and recent studies implicating CTCF in learning and memory (Sams et al., 2016).

\section{Ctcf regulates the expression of Lhx6 and Lhx8 in the MGE}

Lhx6 is required in the developing MGE for the production of $\mathrm{PV}^{+}$and $\mathrm{SST}^{+}$interneuron subtypes that ultimately populate multiple areas of the forebrain, including the striatum and cerebral cortex. qRT-PCR confirmed an $\sim 2$.5-fold decrease in Lhx6 transcript levels $(p=0.028)$. Similarly, the expression of Sst, a known downstream target of LHX6, exhibits an $\sim 10$-fold decrease $(p=0.0001)$ (Fig. $2 A)$. ISH of E13.5 embryonic sections confirmed decreased $\operatorname{Lh} x 6 \mathrm{mRNA}$ and a reduced number of Sst ${ }^{+}$ cells in the $C t c f^{\text {Nes-Cre }}$ MGE and forebrain, respectively (Fig. 2B). We observed that, in a subset of embryos, the reduction in $L h x 6$ expression was restricted to the caudal MGE (data not shown). ISH of Sst transcripts identified fewer $S s t^{+}$cells migrating tangen- tially from the MGE toward the cortex in the Ctcf ${ }^{\mathrm{Nes}-\mathrm{Cre}}$ compared with control embryos (Fig. 2C). Given that CTCF protein expression is not detectable in the MGE of the $C t c f^{\text {Nes-Cre em- }}$ bryos by E12.5 (Watson et al., 2014; Fig. $2 F$ ), we examined Lhx6 expression at this time point by ISH and observed only a subtle decrease in the $C t c f^{\text {Nes-Cre }}$ MGE compared with control (Fig. 2G), suggesting that $L h x 6$ expression is affected in the $C t c f^{\text {Nes-Cre }}$ MGE mostly after E12.5 and this reduction is most pronounced in cells of the posterior MGE.

To eliminate the possibility that the observed reduction in $\operatorname{Lh} x 6$ transcripts could be a consequence of $C t c f$-null neuroprogenitor cell

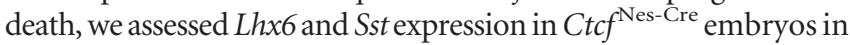
a PUMA-null background. We found that preventing apoptosis of cells in the $C t c f^{\text {Nes-Cre }}$ telencephalon via removal of PUMA failed to rescue the level of $L h x 6$ or Sst (Fig. 2D,E). We next addressed whether the reduction of $L h x 6$ and Sst transcript levels in $C t c f$ mutant embryos is caused by altered proliferation. Acute BrdU incorporation assays showed no significant difference in 
A
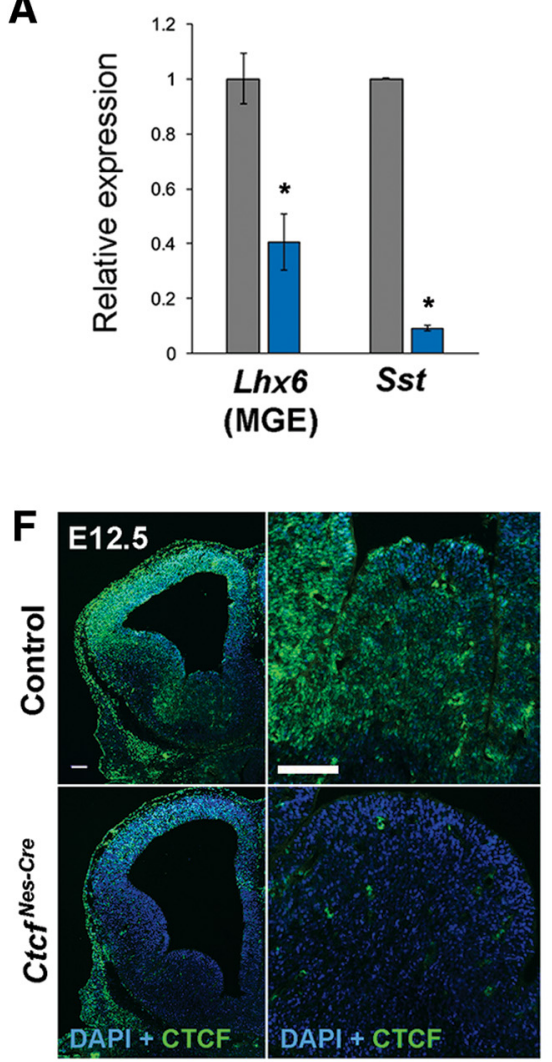
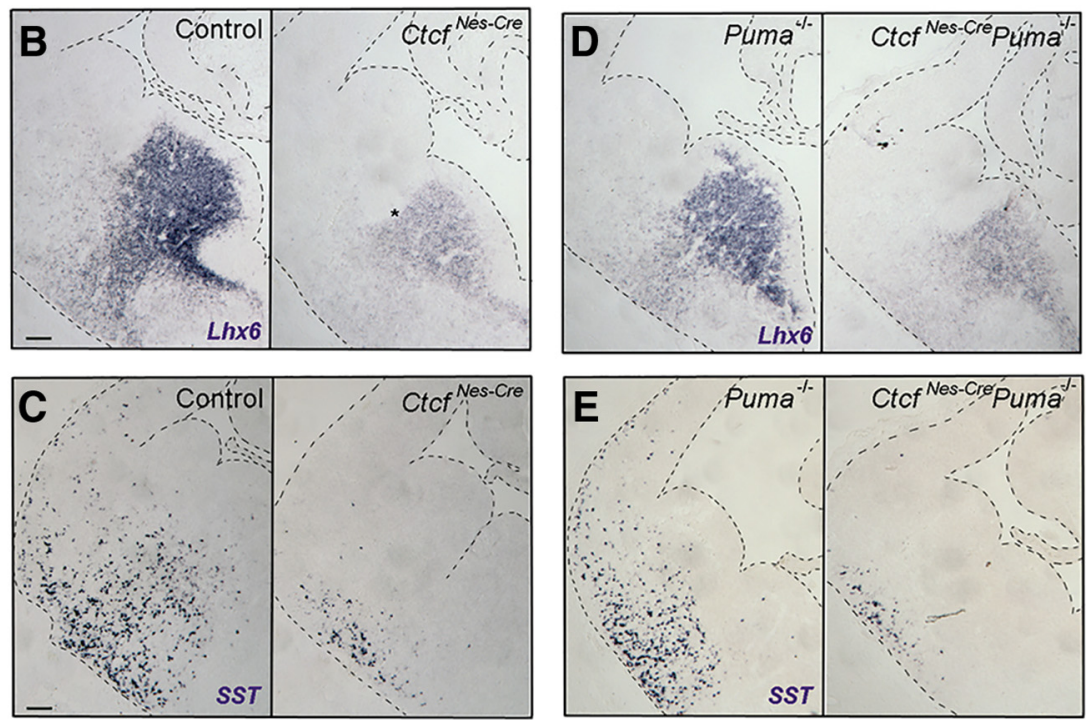

G
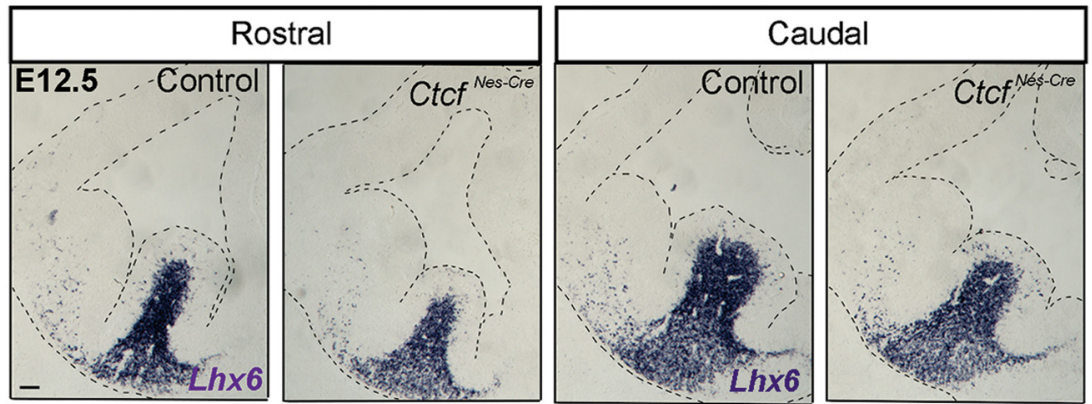
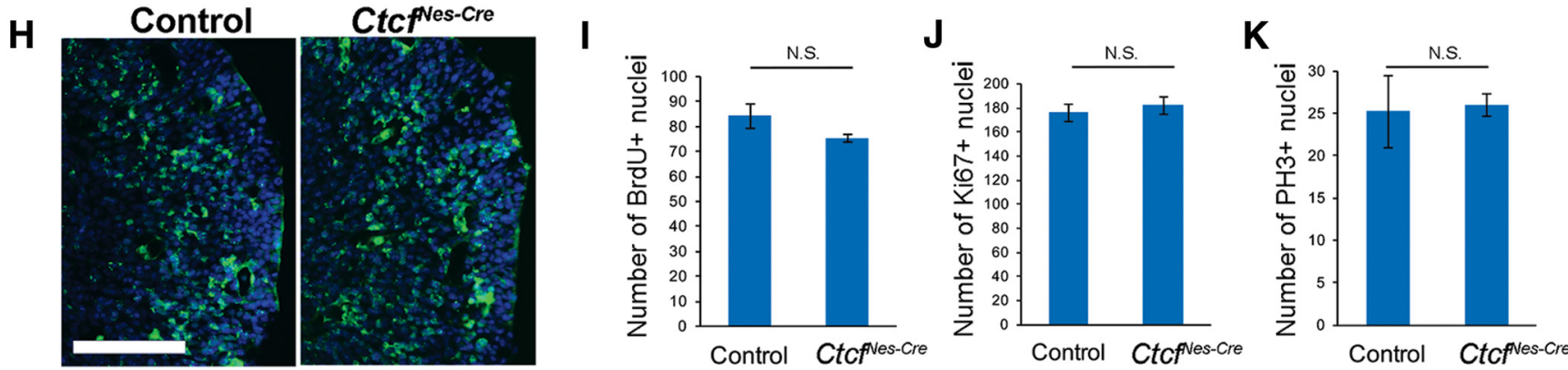

Figure 2. Fewer Lhx6 ${ }^{+}$and Sst ${ }^{+}$cells are present in the CTCF mutant embryonic brain. A, qRT-PCR performed in E14 telencephalon (or MGE) isolated from control (gray) or Ctcf ${ }^{\text {Nes-Cre }}$ (blue) embryos ( $n=3$ pairs). Data were normalized to $\beta$-actin expression. Asterisks indicate $p<0.05$, Student's $t$ test. Error bars indicate SEM. ISH of the indicated transcripts on coronal brain sections of E13.5 control and Ctcf ${ }^{\text {Nes-Cre }}$ embryos (B, C) or PUMA ${ }^{-1-}$ and $C t f^{\text {Nes-Cre }} /$ PUMA $^{-1-}$ embryos (D, E). $\boldsymbol{F}$, CTCF immunofluorescence staining and DAPI counterstain in E12.5 Ctcf ${ }^{\text {Nes-Cre }}$ brain coronal


$\boldsymbol{H}$, BrdU immunofluorescence staining of embryonic MGE section $1 \mathrm{~h}$ after BrdU injection of pregnant dam. $\boldsymbol{I}-\boldsymbol{K}$, Quantification of BrdU ${ }^{+}(\boldsymbol{I}), \mathrm{Ki} 7^{+}(\boldsymbol{J})$, and phosphohistone $\mathrm{H3}\left(\mathrm{PH} 3{ }^{+}\right)(\boldsymbol{K})$ nuclei per $100 \mathrm{~mm}^{2}$ in E12.5 MGE VZ of control and Ctcf ${ }^{\text {Nes-Cre }}$ embryos $(n=3)$. Error bars indicate SEM. Scale bars, $100 \mu \mathrm{m}$. NS, Not significant.

the proliferative capacity of the Ctcf-null neuroprogenitors in the ventricular zone of the MGE at E12.5 (Fig. 2 H,I). Quantification of $\mathrm{Ki}^{+} 7^{+}$and phosphohistone $\mathrm{H}^{+}{ }^{+}\left(\mathrm{PH}^{+}\right)$cells in the MGE confirmed that proliferation is not affected (Fig. $2 J, K$ ). Together, these results indicate that the reduction in Lhx6 and Sst transcripts is not caused by altered survival or proliferative capacity of Ctcf-deficient MGE cells.

Beginning at E9.75, MGE cells are specified in the ventricular zone by Nkx2.1, a transcription factor with MGE-restricted expression that regulates the expression of $\operatorname{Lh} \times 6$ and $\operatorname{Lh} \times 8$. Through unknown mechanisms, a subset of the cells that coexpress these genes become either $\operatorname{Lh} x 6^{+}$or $L h x 8^{+}$(Fragkouli et al., 2009).
Based on findings in Lhx8-deficient mice, LHX8 promotes a genetic program specifying telencephalic cholinergic interneurons that remain in the basal ganglia as striatal interneurons or projection neurons of regions such as the globus pallidus, ventral pallidum, and septum (Zhao et al., 2003). We therefore also examined the effect of CTCF loss on Lhx8 expression by ISH and qRT-PCR of RNA isolated from the MGE. In contrast to Lhx6, the expression of $L h x 8$ was significantly increased compared with control $(p=0.0058)$, suggesting that a greater number of MGE cells retain $L h x 8$ at the expense of $L h x 6$ expression (Fig. $2 A, B$ ). Increased expression of $G b x 2$, a downstream target of $\operatorname{Lhx} 8$ (Zhao et al., 2003), supports a scenario in which Ctcf-null MGE cells 

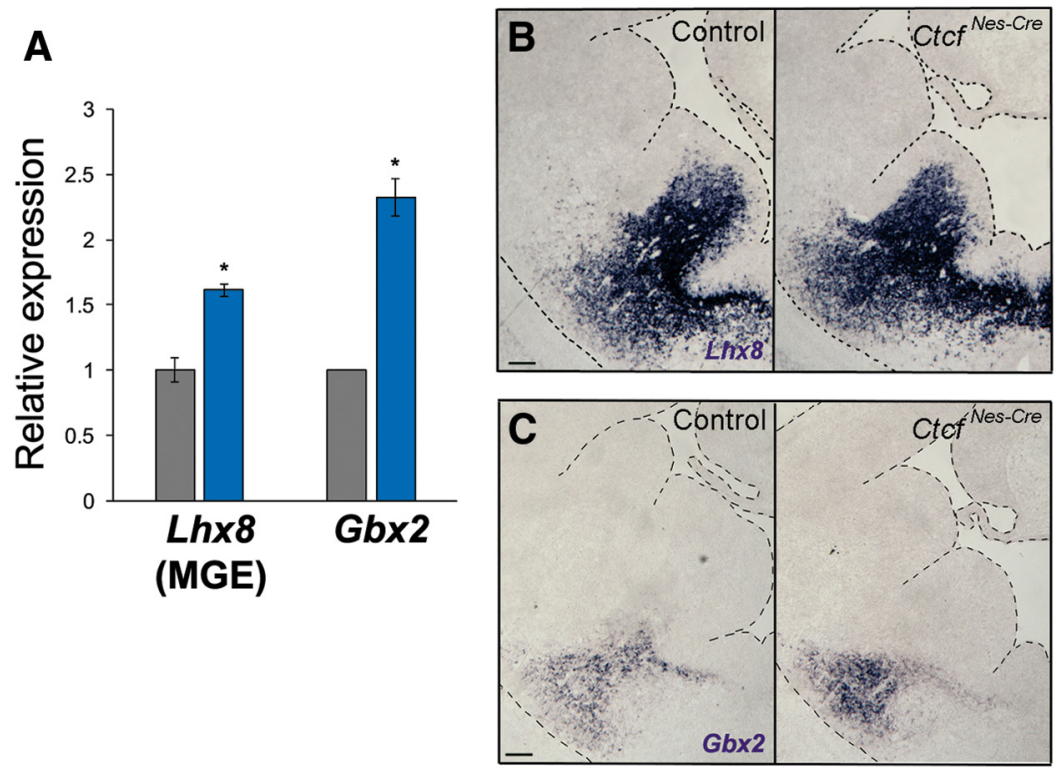

Figure 3. Increased expression of $L h x 8$ and Gbx2 in the Ctcf-null MGE. $A$, qRT-PCR of telencephalon (or MGE) isolated from control (gray) or $C t f^{\text {Nes-Cre }}$ (blue) embryos ( $n=3$ pairs). Data were normalized to $\beta$-actin expression. Asterisks indicate $p<0.05$, Student's $t$ test. Error bars indicate SEM. $B, C$, ISH of $L h \times 8(B)$ and Gbx2 (C) performed on coronal brain sections of control and $\mathrm{CtCf}^{\text {Nes-Cre }}$ E13.5 embryos. Scale bars, $100 \mu \mathrm{m}$. Tissue edges are outlined for ease of visualization.

might implement different fate pathways due to reduced $\operatorname{Lh} x 6$ expression and increased $L h x 8$ expression (Fig. $3 A-C$ ).

\section{CTCF acts independently of NKX2.1 to regulate Lhx6 and Lhx8 expression}

Given that NKX2.1 induces the expression of $L h x 6$ and $L h x 8$, we investigated whether CTCF affects these factors by controlling NKX2.1 expression in the embryonic MGE, but found no evidence that this is the case. Western blot analysis demonstrated that NKX2.1 is not altered in E13.5 Ctcf ${ }^{\text {Nes-Cre }}$ compared with littermate control forebrain (Fig. 4A). We also stained coronal slices of E13.5 Ctcf ${ }^{\text {Nes-Cre }}$ and littermate control embryos with an anti-NKX2.1 antibody, revealing no gross change in NKX2.1 levels or spatial expression (Fig. 4B). We next tested whether CTCF associates with NKX2.1 to regulate $\operatorname{Lh} x 6$ and $\operatorname{Lh} \times 8$ by coimmunoprecipitation of CTCF and NKX2.1 in pooled MGE tissue dissected from wild-type E13.5 embryos and observed no interaction between these two proteins (Fig. 4C). In addition, we compared the chromatin occupancy of these two factors by ChIP-Seq analysis. We performed ChIP-Seq for CTCF using pooled wildtype E13.5 MGE tissue and the data obtained were compared with previously published NKX2.1 ChIP-seq data (Sandberg et al., 2016). We found that only a small percentage of CTCF peaks (6.5\%) overlapped with NKX2.1-binding sites $(p<0.01$, Fig. $4 D$ ). Regulatory elements previously identified in the promoter and in the first intron of $L h x 6$ (Du et al., 2008; Chen et al., 2013) are not bound by CTCF (Fig. 4E). We also examined CTCF binding to several enhancers that have activity in the MGE (Chen et al., 2013): (1) enhancer 422 [chr2:71,373,435-71,374,614 (mm9)], (2) DlxI12b [chr2:71,374,047-71,374,552 (mm9)], (3) the murine sequence corresponding to enhancer 692 near the human SOX6 gene [chr7:122,275,029-122,275,957 (mm9)], (4) the murine sequence corresponding to the human enhancer 1056 [chr18:81, $349,730-81,351,184$ (mm9)], and (5) the murine sequence corresponding to the human enhancer 1538 [chr2:71,373,514-71, 374,608 (mm9)]. No peaks corresponding to CTCF binding were found at any of these sites (data not shown). Conversely, we observed CTCF-binding sites flanking a large genomic region surrounding $L h x 6$, suggesting that CTCF may promote longrange loop formation that is perhaps required for proper regulation of $\operatorname{Lhx} 6$.

We also examined CTCF binding at the $L h x 8$ locus and identified a peak in intron 6 and another $\sim 30 \mathrm{~kb}$ upstream of the gene (Fig. 4E). This pattern of CTCF binding has been observed at other loci that exhibit negative transcriptional regulation by CTCF, including the $B b c 3 /$ PUMA gene (Gomes and Espinosa, 2010). Altogether, these data suggest that CTCF does not affect NKX2.1 levels, but rather acts in parallel (potentially by altering chromatin topology) to control $\operatorname{Lhx} 6$ and Lhx8 expression.

\section{MGE-specific deletion of Ctcf diminishes the number of $\mathrm{Pv}^{+}$and $\mathrm{Sst}^{+} \mathrm{CINs}$}

Although useful for the investigation of early forebrain development, the Ctcf Nes-Cre $^{\text {Ne }}$ mice have some limitations. Extensive cell death ensues beyond E16 in the telencephalon and the mice die in the perinatal period, preventing any postnatal analysis of CINs. To circumvent these difficulties, we conditionally deleted Ctcf in the MGE starting at E10 with the Nkx2.1Cre driver line of mice. Immunofluorescence staining of E13.5 sections confirmed an absence of CTCF expression in most of the MGE, except for the dorsomedial MGE in some embryos, as reported previously (Vogt et al., 2014; Fig. 5A). Importantly, Ctcf deletion in the E13.5 MGE recapitulates differences in $L h x 6$, Sst, and $L h x 8$ transcript levels detected in $C t c f^{\text {Nes-Cre }}$ embryos by qRT-PCR and ISH (Fig. $5 B-D$ ). $C t c f^{\mathrm{Nkx}-\mathrm{Cre}}$ mice are smaller than controls and exhibit failure to thrive postnatally (Fig. $5 E-G$ ). Although this could be caused by the loss of CTCF in the MGE, Nkx2.1-driven Cre expression can sometimes occur in the lung and the thyroid (Minoo et al., 1999), so reduced survival of $C t c f^{\mathrm{Nkx}-\mathrm{Cre}}$ might be caused by Cre-mediated deletion of Ctcf in these tissues. In support of this, we found that circulating thyroxine (T4) levels were reduced in $\mathrm{Ctcf}^{\mathrm{Nkx}-\mathrm{Cre}}$ mice aged P20-P22 (Fig. 5H).

Tangential migration of MGE interneurons into the developing dorsal pallium is mediated by several molecular signals downstream of LHX6, including the interaction of chemoreceptors present on CIN cell surface (CXCR4 and CXCR7), with stromal cell-derived factor 1 (SDF1), which is present in the marginal and intermediate zones of the developing neocortex (Abe et al., 2015). To test for defects in MGE-derived interneuron migration in the $C t c f^{\text {Nkx-Cre }}$ embryos, we introduced the Cre-responsive Rosa$m T m G$ reporter gene that results in GFP expression upon Cre-mediated recombination (Fig. 6A). The number of GFP ${ }^{+}$ MGE-derived cells were identified and counted in the E16.5


significant decrease in the number of $\mathrm{GFP}^{+}$cells in the $C_{t c} f^{\text {Nkx-Cre }}$ neocortex, consistent with a defect in tangential migration to the cortex (Fig. $6 B, C$ ). In support of a migration defect, the expression of Cxcr4 was significantly decreased in the $C t c f^{\text {Nkx-Cre }}$ and Ctcf $f^{\text {Nes-Cre }}$ E14 embryos compared with controls (data not shown).

The extended viability of these mice compared with the Ctcf ${ }^{\text {Nes-Cre }}$ allowed an investigation of CINs at P21, a time when 
A

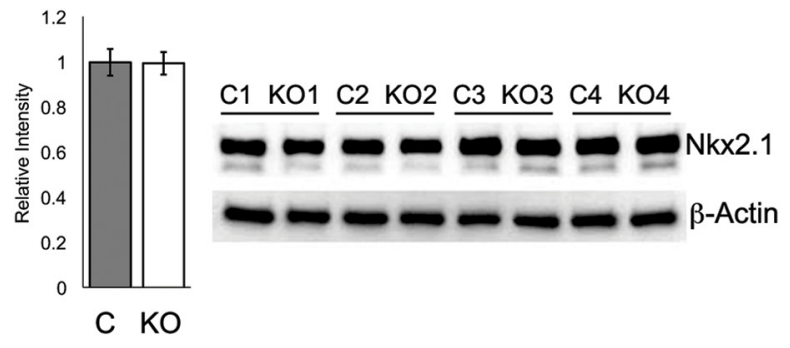



D

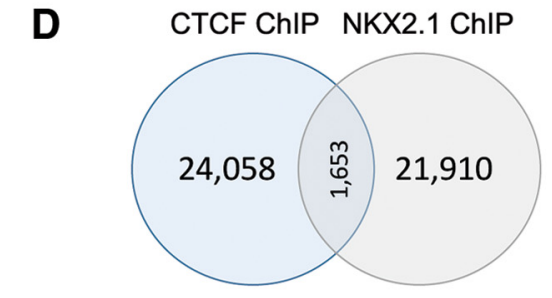

E
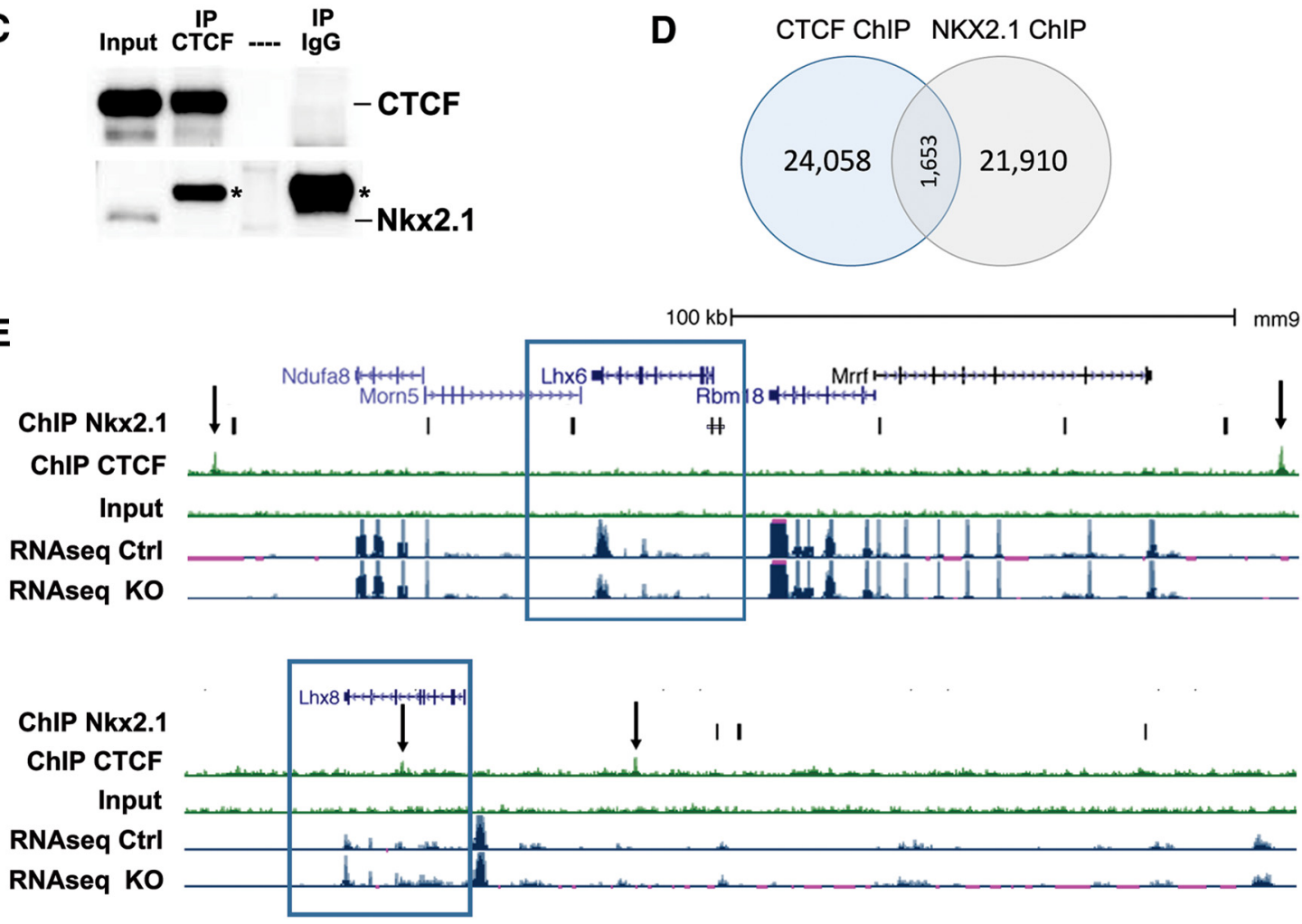

Figure 4. CTCF functions independently of Nkx2.1 to regulate $L h x 6$ and $L h x 8$. A, Western blot of Nkx2.1 in E13.5 telencephalon of controls and $C t f^{\text {Nes-Cre }}$ (K0) embryos. $\beta$-actin was used for normalization. Quantification is shown graphically on the right. Error bars indicate SEM. $p=0.968$, Student's $t$ test. $\boldsymbol{B}$, Nkx2.1 immunofluorescence staining (red) in E13.5 coronal sections. Nuclei were counterstained with DAPI (blue). Scale bar, $100 \mu \mathrm{m}$. C, Co-IP of CTCF and Nkx2.1 of pooled wild-type MGE tissue. Asterisks indicate nonspecific lgG band. D, Venn diagram showing the overlap of CTCF and Nkx2.1 ChIP-Seq peaks in the MGE $(p<0.01)$. E, Diagram depicting UCSC genome browser views of the Lhx6 and Lhx8 loci (boxed), ChIP-Seq peaks for Nkx2.1, CTCF and input as well as the RNA-Seq tracks of control and Ctcf $f^{\text {Nes-Cre }}$ E14 telencephalon. Key CTCF-binding sites are indicated by arrows.

CIN number and laminar position have attained adult patterns (Del Rio et al., 1992). ISH of brain sections from control and mutant mice revealed that the number of $\mathrm{Pv}^{+}$and $\mathrm{Sst}^{+}$interneurons in the Ctcf ${ }^{\mathrm{Nkx}-\mathrm{Cre}}$ cortex is significantly reduced compared with controls (Fig. 6D-G). We also examined the outcome of CTCF loss on laminar positioning of interneurons by dividing a sampled cortical area into 10 equal bins, with bin 1 corresponding to the most superficial of these (i.e., cortical layer I). This analysis showed that $\mathrm{Sst}^{+}$and $\mathrm{Pv}^{+}$cells in Ctcf ${ }^{\mathrm{Nkx}-\mathrm{Cre}}$ cortices were reduced equally among lamina (data not shown). Because MGE-derived interneurons occupy laminar layers based on developmental time, these findings suggest that $C t c f$ deletion affects MGE interneuron production equally over time.

Deletion of Ctcf results in altered fate and laminar distribution of MGE-derived cells

To further evaluate the postnatal consequences of the transcriptional alterations of $L h x 6$ in the embryonic CTCF-null MGE, we investigated the relative proportion of interneuron subtypes, as well as their respective cortical position, at P21. Despite the observed reduction of $\mathrm{Pv}^{+}$and $\mathrm{Sst}^{+}$cells in the cortex, the total number of CINs (identified by Gad1 staining) was not significantly different (Fig. $7 A, B$ ). Moreover, we observed no difference in the number of Reelin ${ }^{+}$interneurons, a gene expressed in a portion of interneurons originating from the MGE and the CGE (Fig. $7 D, E$ ). However, Reelin ${ }^{+}$interneurons in the $C t c f^{\mathrm{Nkx}-\mathrm{Cre}}$ cortex tend to occupy upper cortical layers at the expense of deeper ones compared with controls (Fig. $7 D, F$ ).

Because CGE-derived interneurons tend to occupy superficial layers, we hypothesized that there was aberrant specification of the MGE-derived cells into CGE-like cells. This possibility is supported by previous work showing that Lhx6 deletion causes a fate switch to more CGE-like subtypes as determined by laminar distribution and marker expression (Vogt et al., 2014). To test whether Ctcf-null MGE-derived cells adopt a CGE-like fate, we examined markers of CGEderived CINs (Vip, Cr, and SP8) (Cai et al., 2013; Ma et al., 2012) in P21 cortex of control and Ctcf $f^{\text {Nkx-Cre }}$ animals. No 



Figure 5. MGE-specific Ctcfdeletion replicates gene expression changes and extends postnatal survival. $A$, CTCF immunofluorescence (green) of E13.5 Ctcf ${ }^{\mathrm{Nkx}-\text { Cre }}$ coronal brain sections. Nuclei are


normalized to $\beta$-actin $(n=3)$. C, D, ISH of Lhx6 and Sst in E13.5 coronal sections. Scale bar, $100 \mathrm{~mm}$. Tissue is outlined for ease of visualization. $\boldsymbol{E}$, Representative image of a 12 -d-old Ctc $^{\text {Nkx-Cre }}$ male mouse and littermate control. $\boldsymbol{F}$, Weight of $C t c f^{\mathrm{Nkx}-\text { Cre }}(n=4)$ and littermate controls $(n=12)$ over time. Error bars indicate SEM. G, Survival curve of $C t c f^{\mathrm{Nkx}-\text {-Cre }}$ mice $($ males $=4$; females $=5)$. Five animals were killed due to severe distress or imminent death. $\boldsymbol{H}$, Quantification of serum T4 from P20 -P22 Ctc $f^{\mathrm{Nkx}-\text { Cre }}$ mice and control siblings by ELISA. Error bars indicate SEM. $n=6$ pairs. Asterisk indicates $p<0.05$ by Student's $t$ test.

significant difference in either total number (Fig. $7 G-L$ ) or laminar position (data not shown) was observed, indicating that Ctcf-null MGE cells, despite expressing low levels of $L h x 6$, do not ectopically express CGE markers. Together, these data indicate that the Ctcf-null MGE cells that migrate tangentially into the cortex appropriately express Gad1, but do not express $\mathrm{Pv}$ or Sst and fail to laminate normally.

\section{Lhx6 reexpression in CTCF-null MGE cells restores}

SST-expressing interneurons and rescues lamination defects when transplanted in a wild-type host cortex

The fate of Ctcf-null MGE interneurons was further evaluated by viral-mediated labeling and transplantation of Ctcf-null or control MGE cells into wild-type host cortex, as described previously (Vogt et al., 2014, 2015). Briefly, the MGE was dissected from E13.5 Ctcf ${ }^{\text {Nkx-Cre }}$ embryos or heterozygous littermate embryos (acting as controls). The MGE was dissociated and either transplanted directly into hosts or transduced with lentiviral constructs before transplantation (Fig. 8A). For phenotyping experiments, the MGE was dissected from $C t c f^{\text {Nkx-Cre embryos }}$ carrying the Cre-sensitive Rosa-mTmG reporter allele to label cells with GFP. The GFP-labeled MGE cells were then transplanted into P1 wild-type host pups. The brains were removed at
P35 and cortical sections were examined by immunofluorescence microscopy.

Immunofluorescence staining for SST revealed a marked reduction $(\sim 50 \%)$ in the number of transplanted Ctcf $f^{\mathrm{Nkx}-\mathrm{Cre}}$ $\mathrm{GFP}^{+}$cells expressing SST compared with controls (Fig. 8B$E, R)$. Conversely, no changes were observed in PV-expressing cells (Fig. $8 \mathrm{~N}-\mathrm{Q}, T$ ). We detected a significantly higher number of $\mathrm{GFP}^{+}$transplanted cells in layer $\mathrm{I}(p<0.0001)$ and a reduction in cortical layer $\mathrm{V}$, similar to the laminar defects observed in the $\mathrm{Ctcf}^{\mathrm{Nkx}-\mathrm{Cre}}$ mice at P21 (Fig. 8U). Importantly, a striking increase in the number of transplanted $C t c f^{\mathrm{Nkx}-\mathrm{Cre}} \mathrm{GFP}^{+}$cells coexpressing Lhx8 was detected (Fig. $8 H-K, S$ ). However, these $\mathrm{GFP}^{+}$/ Lhx $8{ }^{+}$cells did not migrate into the cortex (Fig. $8 H, I$ ), but rather remained close to the injection site (Fig. $9 A, B$ ), indicating that their migratory capacity was defective in the cortical environment, as opposed to $\mathrm{GFP}^{+} / \mathrm{Lhx} 8^{-}$cells.

We reasoned that the reduction of Lhx6 in CTCF-null MGE cells causes the observed phenotypes. To test this, we reexpressed Lhx6 by transducing $C t c f^{\text {Nkx-Cre }}$ MGE cells (this time not expressing the Rosa-mTmG reporter) with the lentiviral construct (Dlx)I12b-GFP-T2A-Lhx6, as described previously (Vogt et al., 2014) (for schema, see Fig. 8A). At P35, twice as many GFP ${ }^{+}$ transplanted cells that had been transduced with $\operatorname{Lh} x 6$ coex- 

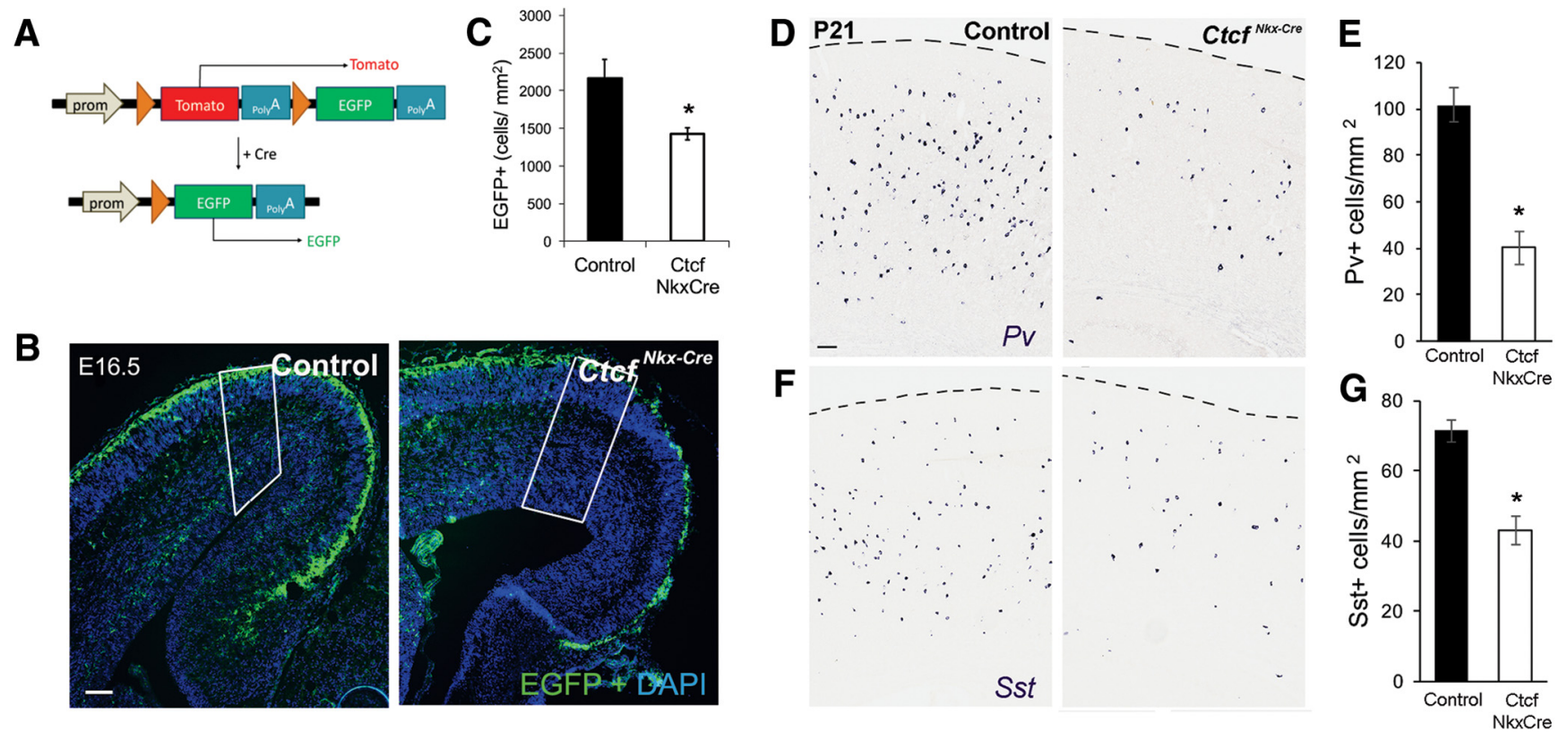

Figure 6. Reduced number of Sst- and Pv-expressing CINs in Ctcf ${ }^{\mathrm{Nkx}-\text { Cre }}$ mice. A, Diagram depicting the Rosa-mTmG allele and the Cre-dependent recombination that results in a switch from red to green fluorescence. Orange arrows represent loxP sites. $\boldsymbol{B}$, Fluorescence microscopy of E16.5 cortical sections of the indicated genotypes after DAPI counterstaining (blue). Green fluorescence is evident in $\mathrm{Cre}^{+}$cells originating from the MGE that are migrating tangentially in the cortex. Note that the red fluorescence channel is not shown. Scale bar, $100 \mu \mathrm{m}$. $N k x$-Cre control animals were used for this experiment. C, Quantification of GFP ${ }^{+}$cells (outlined in white in $\boldsymbol{B}$ ), $n=5$ controls, $n=6$ Ctcf $^{\mathrm{Nkx}-\text {-Cre }}$. D, F, Pv and Sst ISH in the cortex of P21 Ctcf $^{\mathrm{Nkx}-\text { Cre }}$ mice and littermate controls. $E, G$, Quantification of $\mathrm{Pv}^{+}$cells $\left(n=4\right.$ pairs) or Sst ${ }^{+}$cells $(n=3$ pairs). Error bars indicate SEM and asterisks indicate $p<0.05$, Student's $t$ test.

pressed SST (back to normal levels) compared with those transduced with a control vector lacking Lhx6 (Fig. 8R). The lamination defect of $C t c f^{\text {Nkx-Cre }}$ transplanted cells was also rescued upon reexpression of $\operatorname{Lh} x 6$ (Fig. $8 U$ ). However, the proportion of $\mathrm{GFP}^{+} / \mathrm{LHX}^{+}$cells remained high upon forced expression of $L h x 6$, indicating that $L h x 8$ upregulation is probably not a compensatory response to reduced $L h x 6$ levels, but is more likely caused by a failure to repress gene expression in the absence of CTCF. To establish whether the number of transplanted cells was similar between genotypes, we counted the number of GFP ${ }^{+}$ cells observed for each group and normalized this number to the number of tissue sections used for analysis (Table 2). Although the numbers varied between groups, there were trends toward fewer cells being detected in the CTCF cKO and Lhx6 rescued cells compared with controls, suggesting that some cells might be compromised in the CTCF cKO.

\section{CTCF-null MGE-derived cells may acquire a GABAergic projection neuron fate}

Many of the transplanted CTCF-null MGE cells that express LHX8 did not migrate into the cortex and remained close to the injection site (Fig. $9 A, B$ ). Given that many LHX $8^{+}$cells are fated to become cholinergic striatal neurons, we investigated whether they had gained expression of choline acetyltransferase (ChAT), a marker of cholinergic fate. However, only a small proportion of the transplanted $\mathrm{GFP}^{+}$cells coexpressed this marker $(\sim 10.5 \%)$ and most were located near or within the injection site (Fig. $9 C, D, G, H)$. Fate-mapping studies have shown that $\sim 60-70 \%$ of $\mathrm{LHX}^{+}{ }^{+}$cells in the basal forebrain become GABAergic instead of cholinergic (Fragkouli et al., 2005), prompting us to examine transplanted cells for coexpression of GABA. The results indicate that the majority of CTCF-null LHX ${ }^{+}$transplanted cells are in fact GABAergic (Fig. 9E, F).
GBX2, a downstream effector of LHX8, marks either striatal cholinergic neurons $\left(\mathrm{Lhx}_{8}{ }^{+}, \mathrm{Gbx}^{+}\right.$, or $\left.\mathrm{ChAT}^{+}\right)$or GABAergic projection neurons of the basal forebrain $\left(\mathrm{Lhx}^{+}, \mathrm{Gbx}^{+}\right.$, or $\mathrm{ChAT}^{-}$) (Chen et al., 2010). Indeed, upon further examination of the $C t c f^{\text {Nes-Cre }}$ embryos at E15.5 by ISH, we observed more $G b \times 2^{+}$and $L h x 8^{+}$cells that migrate radially from the MGE to the globus pallidus (Fig. $9 E-H$ ), suggesting that loss of Ctcf in MGE cells may respecify a portion of Lhx6 ${ }^{+}$GABAergic cells destined for the cortex to Lhx ${ }^{+}$GABAergic projection neurons that instead migrate radially into the basal forebrain.

\section{Discussion}

The MGE is a transient progenitor zone that generates a variety of different cell types, including GABAergic cortical and striatal interneurons, cholinergic striatal interneurons, and GABAergic and cholinergic projection neurons (Xu et al., 2008; Fragkouli et al., 2009; Flandin et al., 2010; Zechel et al., 2014). The mechanism of genetic programming in the MGE that allows for this cellular diversity is the subject of intense research. The present study advances knowledge of these events by demonstrating that CTCF, a factor involved in higher-order organization of chromatin structure, is required for fate specification of interneurons born in the MGE. Loss of CTCF alters the balance between GABAergic cells fated to become CINs versus basal forebrain projection neurons through the regulation of the LHX6 and LHX8 LIM homeodomain factors.

Expression of $L h x 6$ and $L h x 8$ was altered upon Ctcf inactivation, whereas the upstream regulator NKX2.1 remained unaffected. Moreover, we found no evidence that CTCF interacts with NKX2.1 or cooccupies binding sites in E13.5 MGE chromatin around $L h x 6$ and $L h x 8$ gene loci. Alternate possibilities for regulation must therefore be considered, such as effects on another NKX2.1-binding partner upon Ctcf deletion or that CTCF is re- 




Figure 7. CTCF is required for CIN distribution across cortical layers. $A, D, G, I$, ISH of P21 cortices with the indicated probes. $B, E, H, J$, Quantification of cortical cell densities. Error bars indicate mean \pm SEM. $\boldsymbol{C}, \boldsymbol{F}$, The cortex was divided into 10 horizontal bins, where Bin 1 represents the most superficial layer. Two-way repeated-measures ANOVA was significant for both Gad 1 and Reelin. Student's $t$ test was performed for each bin and significantly different bins $(p<0.05)$ are marked by asterisks (not corrected for multiple testing). $\boldsymbol{K}$, Immunofluorescence staining for SP8 (red) in P21 cortex counterstained with DAPI. Merged blue and red channels are shown. Scale bar, $100 \mu \mathrm{m}$. Bottom inset shows higher magnification of SP8 ${ }^{+}$cells. L, Quantification of SP8 ${ }^{+}$cells. Error bars indicate mean \pm SEM, $n=3$ pairs. $p=0.432$, Student's $t$ test.

quired to set up the specific chromatin architecture permissive for NKX2.1 binding without direct protein-protein interaction.

Deletion of another genome organizer, Special AT-rich DNA Binding Protein 1 (Satb1), also impairs differentiation of SST ${ }^{+}$ interneurons (Denaxa et al., 2012), corroborating the idea that chromatin organization is a key regulatory mechanism of cell fate specification and differentiation of MGE-derived cells. CTCF has been shown in other models to influence gene expression by modulating looping, topological chromatin domains, and enhancer binding (Oti et al., 2016). Additional studies will be required to precisely uncover how CTCF affects chromatin structure and gene expression in the MGE.
Decreased expression of Lhx6 upon loss of Ctcf is associated with fewer Sst ${ }^{+}$and $\mathrm{Pv}^{+}$interneurons in the cortex. We were able to show that the effect on $\mathrm{Sst}^{+}$interneurons results from low Lhx6 expression because lentiviral transduction of $L h x 6$ in Ctcfnull MGE cells fully reinstated the number of Sst ${ }^{+}$CINs to control levels in transplantation experiments. However, the transplantation studies failed to replicate a loss of $\mathrm{PV}^{+}$interneurons seen in the $C t c f^{\mathrm{Nkx}-C r e}$ model. Transplantation experiments were performed in a CD1 background to maximize litter size, whereas the P20-P22 Ctcf $f^{\mathrm{Nkx}-\mathrm{Cre}}$ mice were generated in the $\mathrm{C} 57 \mathrm{BL} / 6$ strain. It is therefore conceivable that there is a variable necessity for Lhx6 expression in different mouse strains/genetic 
A



Genotypes of MGE cells:

Nkx2.1-Cre ${ }^{+} ; \mathrm{CTCF}^{\mathrm{Flox} /+} ; \mathrm{mTmGFlox/+}$ or Nkx2.1-Cre ${ }^{+}$; CTCFFlox/Flox; mTmGFlox/+ or Nkx2.1-Cre ${ }^{+}$; CTCFFlox/Flox

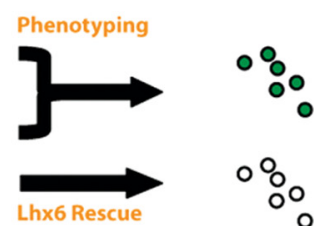

0 \%
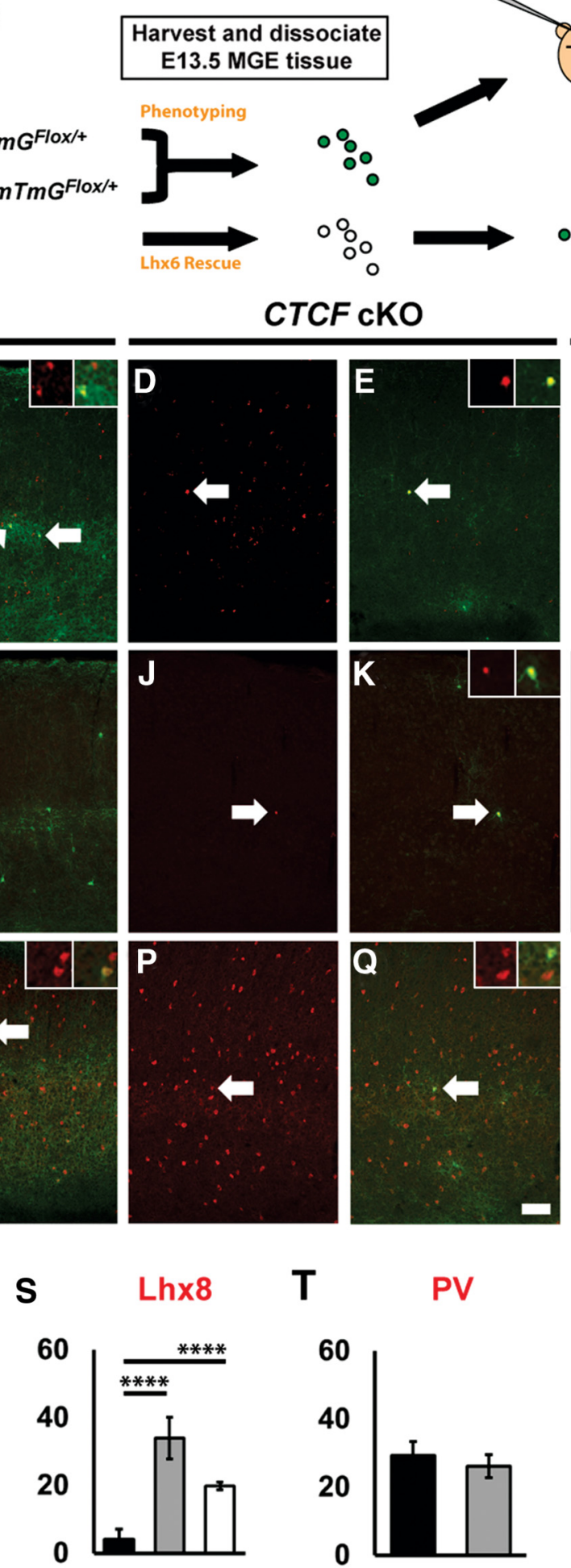

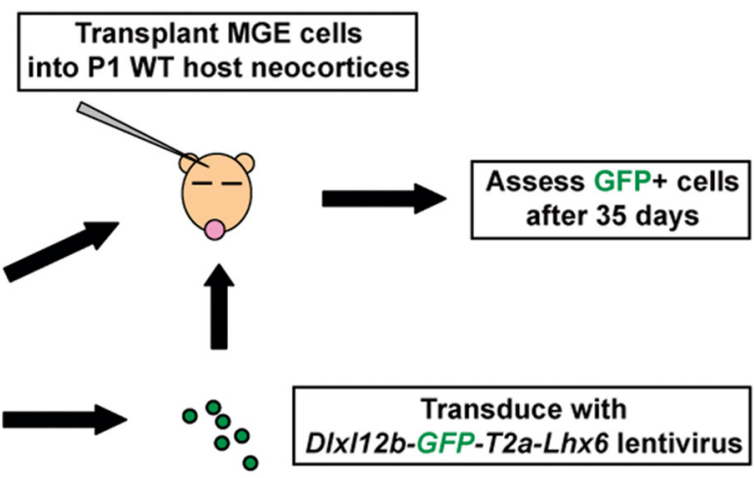

\section{CTCF cKO/Lhx6 Rescue}


Figure 8. Analysis of transplanted CTCF-null MGE cells and rescue by ectopic Lhx6 expression. $\boldsymbol{A}$, Schema depicting the MGE transplantation and rescue strategy. Briefly, Ctcf Nkx-Cre heterozygote (cHets) and knock-out (cKO) MGE cells or CTCF cKO MGE cells transduced with a lentivirus expressing Lhx6 were transplanted in the cortex of wild-type neonatal pups. After 35 d, transplanted cells were assessed for GFP and SST $(\boldsymbol{B}-\mathbf{G})$, Lhx8 $(\boldsymbol{H}-\boldsymbol{L})$, or PV $(\boldsymbol{N}-\mathbf{Q})$. Arrows denote colabeled cells and higher-magnification images of colabeled cells are shown in the top right corners. Quantification of the proportion of GFP ${ }^{+}$cells that coexpress SST $(\boldsymbol{R})$, LHX8(S), or PV $(\boldsymbol{T})$. Quantification of the proportion of GFP ${ }^{+}$cells that occupy different cortical lamina $(\boldsymbol{U})$. IS, Injection site. Data are expressed as the mean \pm SEM. $n=3$ for all groups. ${ }^{* *} p<0.01,{ }^{* * *} p<0.0001$. Scale bar in $\mathbf{Q}, 100 \mu \mathrm{m}$. 

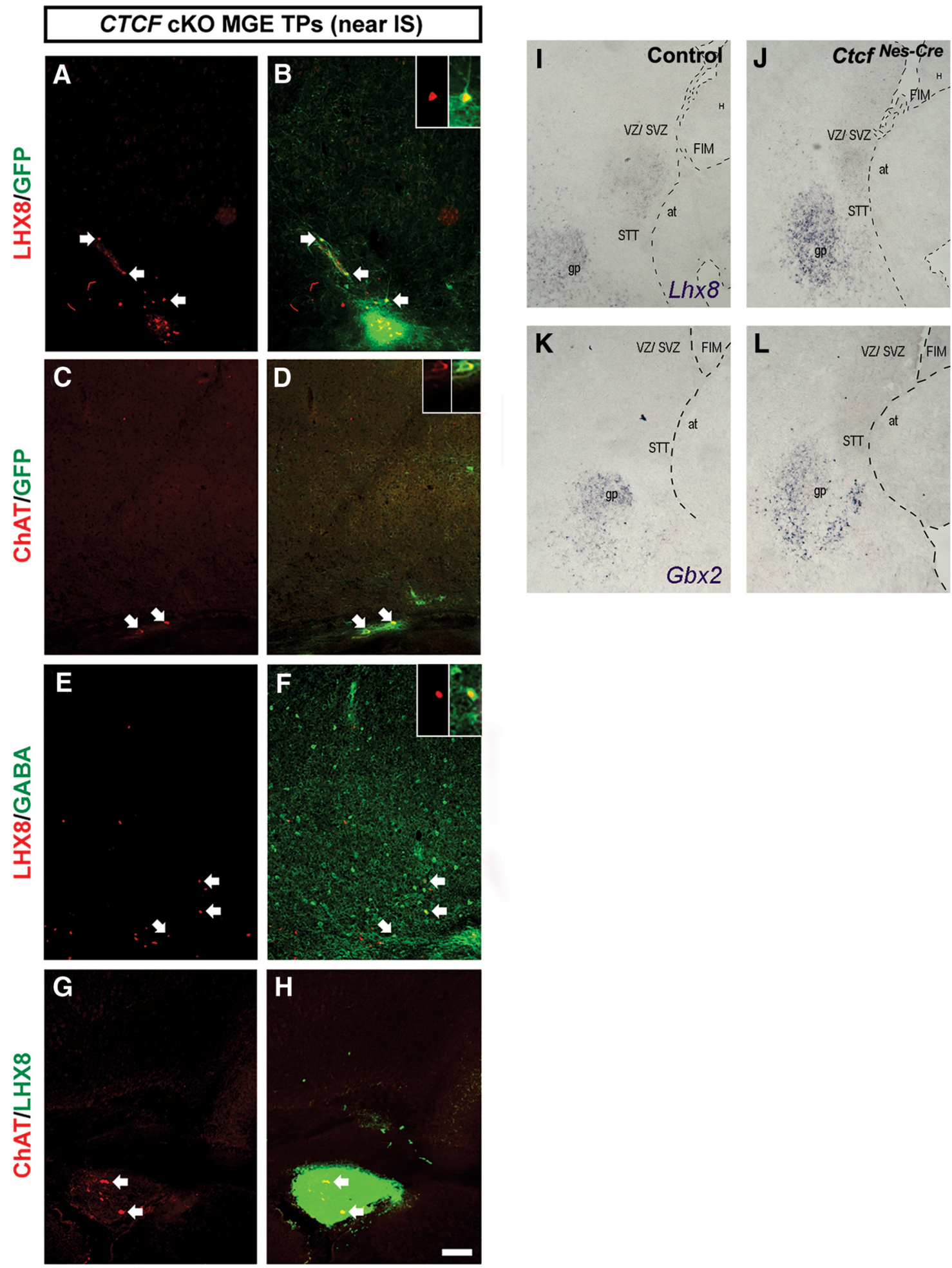

Figure 9. Potential alternate fate of CTCF-null MGE cells to GABAergic projection neurons of the basal ganglia. $\boldsymbol{A}-\boldsymbol{H}$, Transplanted CTCF-null MGE cells remain in proximity to the injection site (IS) and tend to coexpress Lhx8 and GABA, whereas few coexpress ChAT.I,J, A greater number of Lhx8 ${ }^{+}$and Gbx2 ${ }^{+}$cells are observed in the basal forebrain of Ctcf $f^{\mathrm{Nes}-\mathrm{Cre}}$ E15.5 embryonic brain. VZ/SVZ, Ventricular and subventricular zones; FIM, fimbria; at, anterior thalamic nucleus; STT, stria terminalis; gp, globus pallidus.

backgrounds for Pv expression. Alternatively, the $\mathrm{Pv}^{+}$interneurons that are lost in the genetic mouse model may fail to reach the neocortex. Although transplanted MGE cells can still migrate to the neocortex where they are injected, they do not experience the same obstacles encountered by endogenous MGE-derived cells that migrate tangentially into the neocortex. It is possible that the cells fated to become $\mathrm{Pv}^{+}$may be more affected by migration than by fate, although this remains to be determined. Additionally, a similar phenomenon has been described previously (Neves et al., 2013) using a hypomorphic allele of $L h x 6$, which resulted in 


\begin{tabular}{|c|c|c|c|c|c|c|}
\hline $\begin{array}{l}\text { Transplanted } \\
\text { MGE cells }\end{array}$ & $n$ & $\begin{array}{l}\text { No. of } \\
\text { transplanted } \\
\text { cells }\end{array}$ & $\begin{array}{l}\text { No. of } \\
\text { brain sections } \\
\text { assayed }\end{array}$ & $\begin{array}{l}\text { No. of } \\
\text { cells/section }\end{array}$ & $\begin{array}{l}\text { Mean no. of } \\
\text { cells/section }\end{array}$ & SEM \\
\hline \multirow[t]{3}{*}{ CTCF CHet } & $1^{\text {st }}$ & 219 & 42 & 5.21 & \multirow[t]{3}{*}{8.68} & \multirow[t]{3}{*}{1.88} \\
\hline & $2^{\text {nd }}$ & 490 & 42 & 11.67 & & \\
\hline & $3^{\text {rd }}$ & 357 & 39 & 9.15 & & \\
\hline \multirow[t]{3}{*}{ CTCF CKO } & $1^{\text {st }}$ & 76 & 36 & 2.11 & \multirow[t]{3}{*}{4.65} & \multirow[t]{3}{*}{1.29} \\
\hline & $2^{\text {nd }}$ & 248 & 45 & 5.51 & & \\
\hline & $3^{\text {rd }}$ & 266 & 42 & 6.33 & & \\
\hline \multirow{3}{*}{$\begin{array}{l}C T C F \text { CK0/Lhx6 } \\
\text { rescue }\end{array}$} & $1^{\text {st }}$ & 161 & 24 & 6.71 & \multirow[t]{3}{*}{4.79} & \multirow[t]{3}{*}{0.96} \\
\hline & $2^{\text {nd }}$ & 88 & 24 & 3.67 & & \\
\hline & $3^{\mathrm{rd}}$ & 96 & 24 & 4.00 & & \\
\hline
\end{tabular}

loss of SST, but not PV interneuron subtypes. Together with the work presented here, these data suggest that the role of LHX6 is stricter for $\mathrm{Sst}^{+}$subtype specification and that its role in $\mathrm{Pv}^{+}$ subtype specification may be compensated for in different genetic backgrounds.

Lhx6-null MGE cells were previously found to undergo a partial fate switch to CGE-like cells (Vogt et al., 2014), but we did not observe this phenomenon in the CTCF-null MGE cells, indicating that only complete loss of $L h x 6$ expression enacts a switch to CGE-like fate. Lhx6 deletion models show defective tangential migration of interneurons into the cortex, which we also observed with deletion of Ctcf in the MGE. Reduced expression of the CXCR4 chemoreceptor would be predicted to contribute to this phenotype. By weaning age, however, the Ctcf mutants had the same number of $\mathrm{Gadl}^{+} \mathrm{CINs}$, suggesting that misspecified CTCF-null MGE cells have delayed tangential migration but eventually populate the cortex, albeit with abnormal distribution, based on Reelin positivity. These findings also suggest that CTCF-null CINs are appropriately specified to GABAergic fate but fail to express Pv or Sst. This is not surprising because the factors that govern Gad1 expression are controlled by different transcriptional pathways that work in parallel to LHX6/LHX8. Lhx6 mutants remain GAD $1^{+}$but exhibit an MGE-to-CGE fate switch (Liodis et al., 2007; Vogt et al., 2014) and $N k \times 2.1$ mutants remain GAD $1^{+}$with an MGE-to-LGE fate switch (Sussel et al., 1999).

Ctcf deletion in MGE cells also resulted in increased expression of $L h x 8$, which is an interesting observation because it could explain the higher number of $G b \times 2^{+}$cells in the basal forebrain in the Ctcf $f^{\text {Nes-Cre }}$ embryos. These cells could potentially represent basal forebrain GABAergic neurons that project to the cortex. This is supported by the observation that transplanted Ctcf-null cells coexpressed LHX8 and GABA at the injection site, whereas very few expressed ChAT, a marker of cholinergic neurons. Reexpression of Lhx6 was not sufficient to reduce the number of LHX8 ${ }^{+}$cells to normal levels in transplantations, which could be explained by reduced functionality of the DlxI12b enhancer to reexpress $\operatorname{Lh} x 6$ in $\operatorname{Lhx} 8^{+}$ Ctcf-null cells or may suggest that LHX8 overexpression is a result of CTCF loss and not downstream of reduced Lhx6 expression.

Understanding the molecular control switches in cell fate specification of MGE cells is relevant to the in vitro differentiation of these progenitors to specific neuron types and in the treatment of human neurological disorders (Danjo et al., 2011; Chohan and Moore, 2016; Chen et al., 2016). The genetic pathways in MGE differentiation and specification are highly conserved between mouse and human (Hansen et al.,
2013; Wang et al., 2014; Ahn et al., 2016), so delineating the molecular events that regulate MGE development can improve our ability to effectively generate MGE-derived cell subtypes from human stem cells. CTCF mutations in humans can result in intellectual disability (Gregor et al., 2013), ASD (Chang et al., 2015), and conditions with altered GABAergic neuron function (Blatt and Fatemi, 2011; Smith-Hicks, 2013). In addition, CTCF has been associated with schizophrenia (Juraeva et al., 2014), which has also been linked with defects in LHX6 (Volk et al., 2014). Our study implicates CTCF in fate specification and migration of MGE progenitors and complements current efforts to understand MGE development from the perspective of chromatin regulators.

\section{References}

Abe P, Molnár Z, Tzeng YS, Lai DM, Arnold SJ, Stumm R (2015) Intermediate progenitors facilitate intracortical progression of thalamocortical axons and interneurons through CXCL12 chemokine signaling. J Neurosci 35:13053-13063. CrossRef Medline

Ahn S, Kim TG, Kim KS, Chung S (2016) Differentiation of human pluripotent stem cells into medial ganglionic eminence vs. caudal ganglionic eminence cells. Methods 101:103-112. CrossRef Medline

Bastaki F, Nair P, Mohamed M, Malik EM, Helmi M, Al-Ali MT, Hamzeh AR (2017) Identification of a novel CTCF mutation responsible for syndromic intellectual disability: a case report. BMC Med Genet 18:68. CrossRef Medline

Bérubé NG, Mangelsdorf M, Jagla M, Vanderluit J, Garrick D, Gibbons RJ, Higgs DR, Slack RS, Picketts DJ (2005) The chromatin-remodeling protein ATRX is critical for neuronal survival during corticogenesis. J Clin Invest 115:258-267. CrossRef Medline

Blatt GJ, Fatemi SH (2011) Alterations in GABAergic biomarkers in the autism brain: research findings and clinical implications. Anat Rec (Hoboken) 294:1646-1652. CrossRef Medline

Cai Y, Zhang Q, Wang C, Zhang Y, Ma T, Zhou X, Tian M, Rubenstein JL, Yang Z (2013) Nuclear receptor COUP-TFII-expressing neocortical interneurons are derived from the medial and lateral/caudal ganglionic eminence and define specific subsets of mature interneurons. J Comp Neurol 521:479-497. CrossRef Medline

Chang J, Gilman SR, Chiang AH, Sanders SJ, Vitkup D (2015) Genotype to phenotype relationships in autism spectrum disorders. Nat Neurosci 18: 191-198. CrossRef Medline

Chen CY, Plocik A, Anderson NC, Moakley D, Boyi T, Dundes C, Lassiter C, Graveley BR, Grabel L (2016) Transcriptome and in vitro differentiation profile of human embryonic stem cell derived NKX2.1-positive neural progenitors. Stem Cell Rev 12:744-756. CrossRef Medline

Chen L, Chatterjee M, Li JY (2010) The mouse homeobox gene Gbx2 is required for the development of cholinergic interneurons in the striatum. J Neurosci 30:14824-14834. CrossRef Medline

Chen YJ, Vogt D, Wang Y, Visel A, Silberberg SN, Nicholas CR, Danjo T, Pollack JL, Pennacchio LA, Anderson S, Sasai Y, Baraban SC, Kriegstein AR, Alvarez-Buylla A, Rubenstein JL (2013) Use of "MGE enhancers" for labeling and selection of embryonic stem cell-derived medial ganglionic eminence (MGE) progenitors and neurons. PLoS One 8:e61956. CrossRef Medline

Chohan MO, Moore H (2016) Interneuron progenitor transplantation to treat CNS dysfunction. Front Neural Circuits 10:64. CrossRef Medline

Danjo T, Eiraku M, Muguruma K, Watanabe K, Kawada M, Yanagawa Y, Rubenstein JL, Sasai Y (2011) Subregional specification of embryonic stem cell-derived ventral telencephalic tissues by timed and combinatory treatment with extrinsic signals. J Neurosci 31:1919-1933. CrossRef Medline

Del Rio JA, Soriano E, Ferrer I (1992) Development of GABA-immunoreactivity in the neocortex of the mouse. J Comp Neurol 326:501-526. CrossRef Medline

Denaxa M, Kalaitzidou M, Garefalaki A, Achimastou A, Lasrado R, Maes T, Pachnis V (2012) Maturation-promoting activity of SATB1 in MGEderived cortical interneurons. Cell Reports 2:1351-1362. CrossRef Medline

Dobin A, Davis CA, Schlesinger F, Drenkow J, Zaleski C, Jha S, Batut P, Chaisson M, Gingeras TR (2013) STAR: ultrafast universal RNA-Seq aligner. Bioinformatics 29:15-21. CrossRef Medline 
Du T, Xu Q, Ocbina PJ, Anderson SA (2008) NKX2.1 specifies cortical interneuron fate by activating Lhx6. Development 135:1559-1567. CrossRef Medline

Flandin P, Kimura S, Rubenstein JL (2010) The progenitor zone of the ventral medial ganglionic eminence requires Nkx2-1 to generate most of the globus pallidus but few neocortical interneurons. J Neurosci 30:28122823. CrossRef Medline

Fragkouli A, Hearn C, Errington M, Cooke S, Grigoriou M, Bliss T, Stylianopoulou F, Pachnis V (2005) Loss of forebrain cholinergic neurons and impairment in spatial learning and memory in LHX7-deficient mice. Eur J Neurosci 21:2923-2938. CrossRef Medline

Fragkouli A, van Wijk NV, Lopes R, Kessaris N, Pachnis V (2009) LIM homeodomain transcription factor-dependent specification of bipotential MGE progenitors into cholinergic and GABAergic striatal interneurons. Development 136:3841-3851. CrossRef Medline

Gibson JR, Bartley AF, Hays SA, Huber KM (2008) Imbalance of neocortical excitation and inhibition and altered UP states reflect network hyperexcitability in the mouse model of fragile X syndrome. J Neurophysiol 100: 2615-2626. CrossRef Medline

Gomes NP, Espinosa JM (2010) Gene-specific repression of the p53 target gene PUMA via intragenic CTCF-cohesin binding. Genes Dev 24:10221034. CrossRef Medline

Gregor A, Oti M, Kouwenhoven EN, Hoyer J, Sticht H, Ekici AB, Kjaergaard S, Rauch A, Stunnenberg HG, Uebe S, Vasileiou G, Reis A, Zhou H, Zweier C (2013) De novo mutations in the genome organizer CTCF cause intellectual disability. Am J Hum Genet 93:124-131. CrossRef Medline

Hammad M, Schmidt SL, Zhang X, Bray R, Frohlich F, Ghashghaei HT (2015) Transplantation of GABAergic interneurons into the neonatal primary visual cortex reduces absence seizures in stargazer mice. Cereb Cortex 25:2970-2979. CrossRef Medline

Hansen DV, Lui JH, Flandin P, Yoshikawa K, Rubenstein JL, Alvarez-Buylla A, Kriegstein AR (2013) Non-epithelial stem cells and cortical interneuron production in the human ganglionic eminences. Nat Neurosci 16: 1576-1587. CrossRef Medline

Hashemi E, Ariza J, Rogers H, Noctor SC, Martínez-Cerdeño V (2017) The number of parvalbumin-expressing interneurons is decreased in the medial prefrontal cortex in autism. Cereb Cortex 27:1931-1943. CrossRef Medline

Heath H, Ribeiro de Almeida C, de Sleutels F, Dingjan G, van de Nobelen S, Jonkers I, Ling KW, Gribnau J, Renkawitz R, Grosveld F, Hendriks RW, Galjart N (2008) CTCF regulates cell cycle progression of $\alpha \beta$ T cells in the thymus. EMBO J 27:2839-2850. CrossRef Medline

Hirayama T, Tarusawa E, Yoshimura Y, Galjart N, Yagi T (2012) CTCF is required for neural development and stochastic expression of clustered pcdh genes in neurons. Cell Reports 2:345-357. CrossRef Medline

Iossifov I, O’Roak BJ, Sanders SJ, Ronemus M, Krumm N, Levy D, Stessman HA, Witherspoon KT, Vives L, Patterson KE, Smith JD, Paeper B, Nickerson DA, Dea J, Dong S, Gonzalez LE, Mandell JD, Mane SM, Murtha MT, Sullivan CA, et al. (2014) The contribution of de novo coding mutations to autism spectrum disorder. Nature 515:216-221. CrossRef Medline

Juraeva D, Haenisch B, Zapatka M, Frank J, GROUP Investigators, PSYCHGEMS SCZ Working Group, Witt SH, Mühleisen TW, Treutlein J, Strohmaier J, Meier S, Degenhardt F, Giegling I, Ripke S, Leber M, Lange C, Schulze TG, Mössner R, Nenadic I, Sauer H, et al. (2014) Integrated pathway-based approach identifies association between genomic regions at CTCF and CACNB2 and schizophrenia. PLoS Genet 10:e1004345. CrossRef Medline

Langmead B, Salzberg SL (2012) Fast gapped-read alignment with bowtie 2. Nat Methods 9:357-359. CrossRef Medline

Lawrence M, Huber W, Pagès H, Aboyoun P, Carlson M, Gentleman R, Morgan MT, Carey VJ (2013) Software for computing and annotating genomic ranges. PLoS Comput Biol 9:e1003118. CrossRef Medline

Liodis P, Denaxa M, Grigoriou M, Akufo-Addo C, Yanagawa Y, Pachnis V (2007) Lhx6 activity is required for the normal migration and specification of cortical interneuron subtypes. J Neurosci 27:3078-3089. CrossRef Medline

Love MI, Huber W, Anders S (2014) Moderated estimation of fold change and dispersion for RNA-Seq data with DESeq2. Genome Biol 15:550. CrossRef Medline
Lozano R, Martinez-Cerdeno V, Hagerman RJ (2015) Advances in the understanding of the gabaergic neurobiology of FMR1 expanded alleles leading to targeted treatments for fragile $\mathrm{X}$ spectrum disorder. Curr Pharm Des 21:4972-4979. CrossRef Medline

Ma T, Zhang Q, Cai Y, You Y, Rubenstein JL, Yang Z (2012) A subpopulation of dorsal Lateral/Caudal ganglionic eminence-derived neocortical interneurons expresses the transcription factor Sp8. Cereb Cortex 22: 2120-2130. CrossRef Medline

Marín O (2013) Cellular and molecular mechanisms controlling the migration of neocortical interneurons. Eur J Neurosci 38:2019-2029. CrossRef Medline

Marin O, Anderson SA, Rubenstein JL (2000) Origin and molecular specification of striatal interneurons. J Neurosci 20:6063-6076. CrossRef Medline

Merkenschlager M, Nora EP (2016) CTCF and cohesin in genome folding and transcriptional gene regulation. Annu Rev Genomics Hum Genet 17:17-43. CrossRef Medline

Minoo P, Su G, Drum H, Bringas P, Kimura S (1999) Defects in tracheoesophageal and lung morphogenesis in Nkx2.1(-/-) mouse embryos. Dev Biol 209:60-71. CrossRef Medline

Miyoshi G, Fishell G (2011) GABAergic interneuron lineages selectively sort into specific cortical layers during early postnatal development. Cereb Cortex 21:845-852. CrossRef Medline

Neves G, Shah MM, Liodis P, Achimastou A, Denaxa M, Roalfe G, Sesay A, Walker MC, Pachnis V (2013) The LIM homeodomain protein Lhx6 regulates maturation of interneurons and network excitability in the mammalian cortex. Cereb Cortex 23:1811-1823. CrossRef Medline

Oti M, Falck J, Huynen MA, Zhou H (2016) CTCF-mediated chromatin loops enclose inducible gene regulatory domains. BMC Genomics 17:252. CrossRef Medline

Paluszkiewicz SM, Olmos-Serrano JL, Corbin JG, Huntsman MM (2011) Impaired inhibitory control of cortical synchronization in fragile X syndrome. J Neurophysiol 106:2264-2272. CrossRef Medline

Pérez-Cremades D, Hernández S, Blasco-Ibáñez JM, Crespo C, Nacher J, Varea E (2010) Alteration of inhibitory circuits in the somatosensory cortex of Ts65Dn mice, a model for Down's syndrome. J Neural Transm (Vienna) 117:445-455. CrossRef Medline

Potier MC, Braudeau J, Dauphinot L, Delatour B (2014) Reducing GABAergic inhibition restores cognitive functions in a mouse model of down syndrome. CNS Neurol Disord Drug Targets 13:8-15. CrossRef Medline

Quinlan AR, Hall IM (2010) BEDTools: a flexible suite of utilities for comparing genomic features. Bioinformatics (Oxford) 26:841-842. CrossRef Medline

Ramírez F, Dündar F, Diehl S, Grüning BA, Manke T (2014) deepTools: a flexible platform for exploring deep-sequencing data. Nucleic Acids Res 42(Web Server issue):W187-W191. CrossRef Medline

Ruiz-Mejias M, Martinez de Lagran M, Mattia M, Castano-Prat P, PerezMendez L, Ciria-Suarez L, Gener T, Sancristobal B, García-Ojalvo J, Gruart A, Delgado-García JM, Sanchez-Vives MV, Dierssen M (2016) Overexpression of Dyrk1A, a down syndrome candidate, decreases excitability and impairs gamma oscillations in the prefrontal cortex. J Neurosci 36:3648-3659. CrossRef Medline

Sams DS, Nardone S, Getselter D, Raz D, Tal M, Rayi PR, Kaphzan H, Hakim O, Elliott E (2016) Neuronal CTCF is necessary for basal and experiencedependent gene regulation, memory formation, and genomic structure of BDNF and Arc. Cell Reports 17:2418-2430. CrossRef Medline

Sandberg M, Flandin P, Silberberg S, Su-Feher L, Price JD, Hu JS, Kim C, Visel A, Nord AS, Rubenstein JLR (2016) Transcriptional networks controlled by NKX2-1 in the development of forebrain GABAergic neurons. Neuron 91:1260-1275. CrossRef Medline

Smith-Hicks CL (2013) GABAergic dysfunction in pediatric neurodevelopmental disorders. Front Cell Neurosci 7:269. CrossRef Medline

Southwell DG, Nicholas CR, Basbaum AI, Stryker MP, Kriegstein AR, Rubenstein JL, Alvarez-Buylla A (2014) Interneurons from embryonic development to cell-based therapy. Science 344:1240622. CrossRef Medline

Sussel L, Marin O, Kimura S, Rubenstein JL (1999) Loss of Nkx2.1 homeobox gene function results in a ventral to dorsal molecular respecification within the basal telencephalon: evidence for a transformation of the pallidum into the striatum. Development 126:3359-3370. Medline

Tremblay R, Lee S, Rudy B (2016) GABAergic interneurons in the neocor- 
tex: from cellular properties to circuits. Neuron 91:260-292. CrossRef Medline

Vogt D, Hunt RF, Mandal S, Sandberg M, Silberberg SN, Nagasawa T, Yang Z, Baraban SC, Rubenstein JL (2014) Lhx6 directly regulates arx and CXCR7 to determine cortical interneuron fate and laminar position. Neuron 82:350-364. CrossRef Medline

Vogt D, Wu PR, Sorrells SF, Arnold C, Alvarez-Buylla A, Rubenstein JLR (2015) Viral-mediated labeling and transplantation of medial ganglionic eminence (MGE) cells for in vivo studies. J Vis Exp 98. CrossRef Medline

Volk DW, Edelson JR, Lewis DA (2014) Cortical inhibitory neuron disturbances in schizophrenia: role of the ontogenetic transcription factor Lhx6. Schizophr Bull 40:1053-1061. CrossRef Medline

Wang C, You Y, Qi D, Zhou X, Wang L, Wei S, Zhang Z, Huang W, Liu Z, Liu F, Ma L, Yang Z (2014) Human and monkey striatal interneurons are derived from the medial ganglionic eminence but not from the adult subventricular zone. J Neurosci 34:10906-10923. CrossRef Medline
Watson LA, Wang X, Elbert A, Kernohan KD, Galjart N, Bérubé NG (2014) Dual effect of CTCF loss on neuroprogenitor differentiation and survival. J Neurosci 34:2860-2870. CrossRef Medline

Xu Q, Cobos I, De La Cruz E, Rubenstein JL, Anderson SA (2004) Origins of cortical interneuron subtypes. J Neurosci 24:2612-2622. CrossRef Medline

Xu Q, Tam M, Anderson SA (2008) Fate mapping Nkx2.1-lineage cells in the mouse telencephalon. J Comp Neurol 506:16-29. CrossRef Medline

Zechel S, Zajac P, Lönnerberg P, Ibáñez CF, Linnarsson S (2014) Topographi$\mathrm{cal}$ transcriptome mapping of the mouse medial ganglionic eminence by spatially resolved RNA-Seq. Genome Biol 15:486. CrossRef Medline

Zhang Y, Liu T, Meyer CA, Eeckhoute J, Johnson DS, Bernstein BE, Nusbaum C, Myers RM, Brown M, Li W, Liu XS (2008) Model-based analysis of ChIP-seq (MACS). Genome Biol 9:R137. CrossRef Medline

Zhao Y, Marín O, Hermesz E, Powell A, Flames N, Palkovits M, Rubenstein JL, Westphal H (2003) The LIM-homeobox gene Lhx8 is required for the development of many cholinergic neurons in the mouse forebrain. Proc Natl Acad Sci U S A 100:9005-9010. CrossRef Medline 